\title{
Controls on the geochemistry of suspended sediments from large tropical South American rivers (Amazon, Orinoco and Maroni)
}

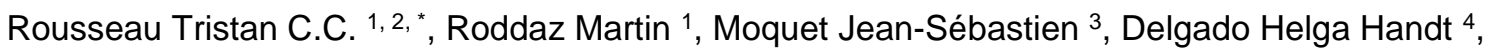 \\ Calves Gérôme ${ }^{1}$, Bayon Germain ${ }^{5}$
}

\author{
${ }^{1}$ GET, Université de Toulouse, CNRS-IRD-OMP, 14 avenue Edouard Belin, 31400 Toulouse, France \\ 2 LABOMAR- Av. da Abolição, 3207, Fortaleza 60165-081, CE, Brazil \\ 3 Institut de Physique du Globe de Paris -, Centre National de la Recherche Scientifique, 1 rue Jussieu, \\ 75005 Paris, France \\ 4 Instituto Venezolano de Investigaciones Cientificas, IVIC Centro de Oceanologia y Estudios Antárticos \\ Carretera Panamericana, Km 11. Altos de Pipe 1020 ${ }^{\underline{a}}$ Venezuela \\ 5 IFREMER, Unité de Recherche Géosciences Marines, F-29280 Plouzané, France \\ * Corresponding author : Tristan C. C. Rousseau, email address : tristanrousseau@ufc.br
}

\begin{abstract}
:
We report mineralogical, elemental (major and trace elements) and SrNd isotopic data for suspended particulate matter (SPM) samples from the Amazon, Orinoco and Maroni Rivers collected on a monthly basis over a one-year long hydrological cycle. The aim of this study was i) to characterize the mineralogical and geochemical composition of major South American tropical rivers and ii) to evaluate the effect of seasonal hydroclimate variations and changes in sediment discharge on the composition of these SPM. In addition to displaying particular mineralogical and geochemical signatures (e.g. Al/Si ratios, weathering indices), the Amazon, Orinoco and Maroni SPM are characterized by marked differences in $87 \mathrm{Sr} / 86 \mathrm{Sr}(0.7213 \pm 0.0030,0.7288 \pm 0.0018$ and $0.7335 \pm 0.0019$, respectively), and $\varepsilon N d$ values $(-10.6 \pm 0.6,-14.1 \pm 0.3$ and $-23.7 \pm 1.2)$, which reflect differences in source rock lithology. While we find no effect of the hydrological cycle on the geochemistry of Orinoco SPM, particulate $\varepsilon \mathrm{Nd}$ and $\mathrm{Cr} / \mathrm{Th}$ signatures fluctuate with the hydrological cycle in the Maroni basin, indicating that they are controlled by variation in rainfall distribution linked to the latitudinal migration of the Intertropical Convergence Zone (ITCZ). In contrast to Maroni and Orinoco SPM, the Amazon SPM are characterized by significant Sr isotope annual variability correlated with suspended sediments discharge and a small but significant $\mathrm{Nd}$ isotopic variability over the year. This latter variation is related to seasonal changes in the rainfall distribution patterns across the Amazon basin, associated with latitudinal migrations of the ITCZ. This suggests that the geochemical composition of the SPM exported over the year from the Amazon Basin faithfully responds to hydroclimate changes related associated with the migration of the rain belt over regions of contrasted geochemical signatures.
\end{abstract}

These findings have implications for the application of $\mathrm{Sr}$ and $\mathrm{Nd}$ isotopes as provenance proxies in sedimentary archives and paleoclimatic studies. The Sr isotopic composition of exported SPM appears to be mostly controlled by weathering processes and/or mineralogical sorting, rather than being indicative of sediment provenance. In contrast, the relationship documented between $\mathrm{Nd}$ isotopes and the 
hydrological variability indicates that their application to archives of past river sediment discharges can provide unique insights on paleo-hydroclimate changes over tropical South America.

\section{Highlights}

- Distinct SPM geochemical signatures exported by tropical South American rivers. Control of source rock lithology and hydrological cycles on these SPM signatures. Potential applications for provenance study and past hydroclimate changes.

Keywords : major and trace elements, $\mathrm{Nd}-\mathrm{Sr}$ isotopes, suspended sediments, yearly hydrological cycle, Amazon River, Orinoco River, Maroni River 


\section{Introduction}

Rivers are the main providers of freshwater and sediment issued from the continents to the oceans. Characterizing land-sea sediment transfers from large river systems is essential for reconstructing global geochemical cycles and nutrient inputs into the oceans, as well as for estimating the fluxes of atmospheric $\mathrm{CO}_{2}$ consumed by silicate weathering and organic carbon burial (Gaillardet et al., 1999; Galy et al., 2007; Meybeck, 1993).

Tropical regions display the world highest rainfall rates and are also particularly sensitive to climate variability (Syvitski et al., 2014; Syvitski and Milliman, 2007), hence with large impact on sediment production and global biogeochemical cycles (Hamilton, 2010; Milliman and Farnsworth, 2011a; Milliman and Farnsworth, 2011b; Syvitski et al., 2003). Previous studies have suggested that the geochemical composition of suspended particulate matter (SPM) and other fine-grained sediments preserved in sedimentary records could reflect past hydrological fluctuations in river basins (e.g. Chiessi et al., 2009; Govin et al., 2014). However, the utility of SPM-based geochemical proxies for paleoclimate studies is complicated by the fact that in tropical/equatorial regions, the chemical and mineralogical composition of the sediment transported by rivers is also strongly dependent on the degree of chemical weathering, the lithology of corresponding drainage basins, and various grain-size effects (Bouchez et al., 2011).

The Amazon and the Orinoco Rivers are the main South American rivers in terms of dissolved and solid fluxes exported to the oceans (Figure 1). The SPM transported by the Amazon River has already been the subject of a number of studies that provided estimates for sediment fluxes and present-day physical denudation rates (Filizola and Guyot, 2004; Gaillardet et al., 1997; Milliman and Meade, 1983). The chemical and mineralogical characterization of Amazon River sediments has also been used i) for provenance studies 
(Basu et al., 1990; Guyot et al., 2007; Guyot et al., 1999; Martinelli et al., 1993; Roddaz et al., 2005; Roddaz et al., 2006; Vital and Stattegger, 2000; Wittmann et al., 2011); ii) to investigate weathering patterns in the Andean mountains and the lowland regions (Allègre et al., 1996; Gaillardet et al., 1997; Gibbs, 1967; Guyot et al., 2007; Sawakuchi et al., 2018; Viers et al., 2008); iii) to constrain sediment residence time within the Amazon Basin (Aalto et al., 2006; Dosseto et al., 2006; Dunne et al., 1998; Meade et al., 1985; Wittmann et al., 2011); and iv) to estimate the chemical composition of the upper continental crust and its evolution through geological time (Allègre et al., 1996; Gaillardet et al., 1997; Goldstein and Jacobsen, 1988; Goldstein et al., 1984). Recent studies have shown that sediment concentration and grain-size distribution of the suspended sediment load in the Amazon Basin was mainly controlled by hydrodynamic sorting (Bouchez et al., 2011). Grain-size sorting can lead to chemical stratification of the SPM in the Amazon River, with suspended sediment loads from the Madeira and Solimões Rivers (i.e. the two main Andean tributaries of the Amazon; Figure 1) being preferentially transported in surface waters and at depth, respectively (Bouchez et al., 2011). In addition, the $\mathrm{Sr}$ isotopic composition of Madeira and Solimões SPM varies in phase with SPM concentrations throughout the hydrological cycle (Viers et al., 2008). This relationship has been ascribed to the fact that increasing physical weathering during the rainy season favours landslides and river bank erosion, which in turn lead to the export of sediments that are generally mobilized under high runoff conditions. To date however, it remains unclear whether or not a similar control of the hydrological cycle on the geochemistry of SPM also exists further downstream of the Amazon Basin, near the mouth of the river.

In comparison with the Amazon River, the Orinoco SPM has received far less attention. No study has ever dealt with the processes that control the geochemistry of the Orinoco SPM. It is unclear whether the hydrological control demonstrated for the SPM composition of the 
Solimões and Madeira Rivers (Viers et al., 2008) also applies to other large rivers in tropical/equatorial South America. Assessing whether such hydrological control exists on the $\mathrm{Sr}-\mathrm{Nd}$ isotopic compositions of SPM is important because $\mathrm{Nd}$ isotopes, and to a lesser extent Sr, are being increasingly used in marine sediment records from the Atlantic Ocean to investigate paleoclimatic variations in South America over various geological timescales (e.g. Hoorn et al., 2017; Höppner et al., 2018; van Soelen et al., 2017; Zhang et al., 2015). The SPM exported by the Solimões and Madeira Rivers is mainly derived from erosion of the Andes. However, smaller rivers like the Maroni (French Guiana) drain exclusively older shield areas, and therefore most likely transport SPM having very contrasted geochemical compositions by comparison with active mountainous SPM sources.

In this study, we report on a detailed investigation of $\mathrm{Sr}-\mathrm{Nd}$ isotopic compositions as well as major and trace element concentrations of SPM from the Amazon, Orinoco and Maroni Rivers, sampled on a monthly-basis over a year-long hydrological cycle. The main goals of this study were i) to characterize the isotopic and geochemical composition of SPM in these rivers, and ii) to evaluate possible systematic temporal variations in the $\mathrm{Sr}-\mathrm{Nd}$ isotope and geochemical compositions of the SPM during the hydrological cycle.

\section{Study area}

Together, the Amazon $\left(5.96 \times 10^{6} \mathrm{~km}^{2}\right)$, Orinoco $\left(1.04 \times 10^{6} \mathrm{~km}^{2}\right)$ and Maroni $\left(0.06 \times 10^{6} \mathrm{~km}^{2}\right)$ river basins occupy around $42 \%$ of the entire South American continent, ranging from about $10^{\circ} \mathrm{N}$ to $20^{\circ} \mathrm{S}$ and from $50^{\circ} \mathrm{W}$ to $80^{\circ} \mathrm{W}$ (Figure 1). The Amazon River ranks first in terms of global mass transfer from the continents to the oceans, supplying about $17 \%$ of the freshwater (Callède et al., 2010), 7\% of the dissolved load (Moquet et al., 2016) and 3\% of the suspended load (Filizola et al., 2011; Guyot et al., 2005; Martinez et al., 2009; Milliman and Farnsworth, 2011b) discharged to the world's oceans. The Orinoco River is the third world 
river in terms of water discharge (Dai and Trenberth, 2002; Laraque et al., 2013b) and contributes to $3 \%, 0.8 \%$ and $0.5 \%$ of the water, dissolved inputs and suspended loads annually exported by world rivers to the oceans, respectively (Laraque et al., 2013a).

Three main geological domains are drained by these rivers: the Andes mountain range, sedimentary plains and shield areas. The Andes covers $15 \%$ and $12 \%$ of the Orinoco and Amazon River basins, respectively. In both basins, the Andes display a large diversity of lithologies that include evaporites, carbonates, granitic rocks, Palaeozoic sedimentary rocks and andesite volcanic rocks (Ahlfeld and Branisa, 1960; Baldock, 1982; INGEMMET, 1999; SERGEOMIN and YPFB, 2000). Sedimentary plains are generally fed by sediments from the Andean mountain range (Junk and Sioli, 1984; Roddaz et al., 2014). In this area, floodplain lakes (várzeas) along the main channels of the Orinoco and Amazon Rivers are seasonally flooded (Dunne et al., 1998; Martinez and Le Toan, 2007; Mertes et al., 1996), playing a significant role in the export of SPM to the main river channel (Bonnet et al., 2008; Bourgoin et al., 2007; Viers et al., 2005). South American shields consist of Precambrian terranes, which provide limited sediment contribution to total solid fluxes carried by both the Amazon and Orinoco basins (Furch and Junk, 1982; Konhauser et al., 1994).

The Solimões and Madeira Rivers are the two main tributaries of the Amazon River issued from the Andean mountains (Figure 1). Together, these two rivers account for approximately $64 \%$ of the total water discharge (Moquet et al., 2016) and almost the entire sediment load annually delivered by the Amazon (Armijos et al., 2013a; Armijos et al., 2013b; Filizola et al., 2011; Laraque et al., 2013a; Laraque et al., 2013b; Moquet et al., 2016). The Negro River drains the Guyana shield in the northern portion of the Amazon, representing 17\% of the Amazon water discharge (Moquet et al., 2016). The Tapajos and the Xingu represent together $10 \%$ of the Amazon water discharge and drain the Brazilian shield. Despite a significant contribution in water discharge, the Negro, Tapajos and Xingú Rivers 
carry very little amount of SPM and account for only 1-2\% of the Amazon sedimentary flux export (Filizola et al., 2011; Filizola and Guyot, 2009).

The Orinoco River receives on its left-bank (northern) margin the Guaviare, Meta, Arauca and Apure Rivers, which drain the northern part of the Andean oriental cordillera and the llanos alluvial deposit. Together, they account for approximately $46 \%$ and $90 \%$ of the total water and sediment discharge, respectively (Meade, 1994). On its right-bank (southern) margin, the Ventuari, Caura and Caroni River tributaries drain the Guyana shield, and account for a total of $54 \%$ of the water discharge, but they contribute to a negligible part of the sediment load (Meade, 1994). By contrast, the Maroni River drains exclusively the Paleoproterozoic terranes of the Guyana shield and exhibit a low content in SPM and dissolved load (Sondag et al., 2010).

The hydroclimate patterns of the studied river basins and associated hydrological regimes are mainly controlled by the Southern American monsoon system (SAMS; Zhou and Lau, 1998) and is dependent on the seasonal variation of the continent-ocean temperature gradients and the migration of the Intertropical Convergence Zone (ITCZ), which moves southward (northward) during the austral summer (winter) (Figure 2; Marengo, 2004; Marengo et al., 2012; Raia and Cavalcanti, 2008). As a consequence, a north-south gradient is typically observed in rainfall rates and seasonality (Espinoza Villar et al., 2009; Molina-Carpio et al., 2017). The Orinoco Basin and the northern and north-western regions of Amazonia receive high rainfall associated with a low seasonality, whereas south-western and southern Amazonia experience lower rainfall associated with high seasonality (i.e. dry and wet seasons during austral winter and summer, respectively). As a consequence, the high discharge periods of the Orinoco, Maroni and Amazon Rivers successively occur from July to October, June to July and March to August, respectively (Guimberteau et al., 2012). The Amazon River exhibits a longer high discharge period because of the phase shift of its main tributaries 
maximum discharge (Bouchez et al., 2017; Moquet et al., 2016). These three basins exhibit a similar range of annual runoff with values ranging between 835 and 1090 mm/yr. However, the seasonality Index (SI), which is the ratio between the highest monthly discharge divided by the lowest one, is much higher for Maroni and Orinoco Rivers, with an SI of around 11, than for Amazon River which exhibits an SI of around 3.

\section{Materials and Methods}

\subsection{Sampling}

Suspended particulate samples from the Amazon, the Orinoco and the Maroni Rivers were collected by the HYBAM observatory (http://www.ore-hybam.org/) (Figure 1). Because of its position upstream the confluence of the Amazon with the Tapajós and Xingu Rivers, the sampling station of Óbidos do not integrate the inputs of these rivers. However, these tributaries are negligible in term of sediment inputs. Mid-section surface river samples were collected monthly from February 2012 to January 2013 in the Amazon River at the Óbidos station $\left(01.9225^{\circ} \mathrm{S} ; 55.6753^{\circ} \mathrm{W}\right)$, from January to December 2008 in the Orinoco River at Ciudad Bolivar station $\left(08.1536^{\circ} \mathrm{N} ; 063.5361^{\circ} \mathrm{W}\right)$ and in the Maroni River at Langa Tabiki station $\left(05.1401^{\circ} \mathrm{S} ; 054.3551^{\circ} \mathrm{W}\right)($ Figure 1$)$.

Daily river discharges are extracted from the HYBAM database (http://www.ore-hybam.org/). SPM concentrations were measured by sampling 300ml of water, filtering and weighting SPM each month. All geochemical and mineralogical results presented in this study were conducted on these filters.

\subsection{Analytical Methods}

\subsubsection{Sample treatments}


Sampling and filtration were done using pre-cleaned HDPE bottles and $0.22 \mu \mathrm{m}$ polyethylsulfone (PES) Millipore ${ }^{\circledR}$ membranes, respectively. After drying and weighting, 1 $\mathrm{cm}^{2}$ fractions of the filters were cut using Teflon scissors for X-ray diffraction analyses (XRD). Suspended particles were extracted from the remaining part of the filters by 3 to 5 repeated ultrasonic baths in ultra-pure water. Solutions were subsequently evaporated at $60^{\circ} \mathrm{C}$ and samples were split into two aliquots having 5-10mg of sediments each: one for major and trace element analyses and the other one for $\mathrm{Nd}$ and $\mathrm{Sr}$ isotopic analyses. The aliquots used for elemental analyses were mixed with 20 to $40 \mathrm{mg}$ of $\mathrm{LiB}$, mineralized by alkali fusion in a Fluxer® and subsequently dissolved and diluted in $2 \% \mathrm{v} / \mathrm{v} \mathrm{HNO}_{3}$. The aliquots for isotopic measurements were first treated with $\mathrm{H}_{2} \mathrm{O}_{2}$ for $24 \mathrm{~h}$ at ambient temperature, then digested in $\mathrm{HNO}_{3}+\mathrm{HF}$ for $36 \mathrm{~h}$ at $80{ }^{\circ} \mathrm{C}$, and in $\mathrm{HCl}+\mathrm{HNO}_{3}$ for $36 \mathrm{~h}$ at $100{ }^{\circ} \mathrm{C}$. Sr and $\mathrm{Nd}$ were separated by ion-exchange chromatography using Sr-SPEC, TRU-SPEC and LN-SPEC resins $\left(\right.$ Eichrom $\left.^{\circledR}\right)$. Ultrapure and double-distilled reagents were used for all digestion and separation steps.

\subsubsection{Sample Analyses}

All analyses were performed at the Géosciences-Environnement-Toulouse (GET) Laboratory - Observatoire Midi-Pyrénées (OMP). XRD analyses were carried out using a G3000 Inel diffractometer $(40 \mathrm{kV}, 30 \mathrm{~mA})$ and Ni-filtered $\mathrm{CuK \alpha 1,2}$ radiation $(\lambda=1.5406 \AA)$. Due to limited amounts of material, we did not perform the glycol treatment, which enables the distinction of inflating clays and allows determination of smectite and chlorite abundances. After subtracting blank filter spectra, peaks of quartz, mica + illite and kaolinite were integrated and converted to relative frequencies.

Major element analyses were done by ICP-OES (Horiba Jobin Yvon Ultima2). Trace element analyses were performed by Quadrupole ICPMS (AGILENT 7500 CE), using a four-point 
calibration and In/Re as internal standards to correct for instrumental drift and matrix effects. Rare earth elements (REE) abundances were corrected from oxide and hydroxide isobaric interferences following Aries et al. (2000). Measurement accuracy was assessed by processing 5 to $10 \mathrm{mg}$ of the GA basalt reference material (CRPG; Centre de Recherches Pétrographiques et Géochimiques), with results being in good agreement with recommended values (Abbey, 1980). Blank values accounted for less than $2 \%$ of the average sample signal, with the exception of $\mathrm{Na}$ analysed with ICP-OES (6\%) and $\mathrm{Cr}, \mathrm{Co}$ and $\mathrm{Ni}$ analysed with ICPMS (6\%, 4\% and 26\% respectively). Despite overall satisfying accuracies on the concentrations determined for the GA reference material, we observed an important fluctuation in the absolute concentrations from one sample to another with $82 \%$ of RSD for the $12 \mathrm{Al}_{2} \mathrm{O}_{3}$ measurements in the Amazon River SPM. This variation is unlikely to be affected by the variation in SPM concentrations and is higher than previous observations of $12 \%$ of RSD for the $18 \mathrm{Al}_{2} \mathrm{O}_{3}$ measurements in the Amazon River SPM by Bouchez et al (2011). Such dispersion in absolute concentrations is probably due to incomplete sample recovery after the $60^{\circ} \mathrm{C}$ evaporation step. This bias did not affect the geological standard because standards were directly weighted without filter extraction. As a consequence, absolute concentrations given in this study should be cautiously used here and be considered as semi-quantitative only. However, this issue should not affect any interpretation based on inter-element relative concentrations (elemental ratios) in each sample, which hence can be used for discussion below.

$\mathrm{Nd}$ and $\mathrm{Sr}$ isotope measurements were conducted on a Thermo Finnigan MAT 261. Nd isotope ratios were measured in static mode, corrected for instrumental mass bias using a ${ }^{146} \mathrm{Nd} /{ }^{144} \mathrm{Nd}$ ratio of 0.7219 . Repeated analyses of the La Jolla standard gave a ${ }^{143} \mathrm{Nd} /{ }^{144} \mathrm{Nd}$ ratio of $0.511867 \pm 0.000018(2 \mathrm{SD}, \mathrm{n}=12)$ in agreement with the recommended value of 
0.511858 (Lugmair et al., 1983). Nd isotopes are reported using the $\varepsilon N d$ notation, normalising samples to the Chondritic Uniform Reservoir (CHUR) value of ${ }^{143} \mathrm{Nd} /{ }^{144} \mathrm{Nd}=0.512638$; (Jacobsen and Wasserburg, 1980):

$$
\text { Equation 1: } \varepsilon N d=\left(\frac{\left({ }^{143} N d /{ }^{144} N d\right)_{\text {measured }}}{\left({ }^{143} N d /{ }^{144} N d\right)_{C H U R}}-1\right) * 10^{4}
$$

Sr isotope ratios were measured in dynamic mode, corrected for instrumental mass bias using ${ }^{87} \mathrm{Sr} /{ }^{86} \mathrm{Sr}=0.1194$. Repeated analyses of the NBS 987 standard gave a ${ }^{87} \mathrm{Sr} /{ }^{86} \mathrm{Sr}$ ratio of $0.710231 \pm 0.000032(2 \mathrm{SD}, \mathrm{n}=15)$ in agreement with the recommended value of Hodell et al. (2007) (0.710240). Blank contributions for Nd and Sr were assessed by ICP-MS and found to be negligible (less than 1 per mil).

\subsection{Elemental ratios diagnostics}

Post-Archaean average Australian shale values (PAAS) were used for normalisation of major and selected trace element data in spider diagrams and rare earth element plots; (Pourmand et al., 2012). In order to minimize the effect of possible bias in absolute concentrations the concentrations in samples where normalised by the corresponding $\mathrm{Al}_{2} \mathrm{O}_{3}$ concentrations and these ratios were normalized against the $[\mathrm{X}]_{\text {PAAS }} /\left[\mathrm{Al}_{2} \mathrm{O}_{3}\right]_{\text {PAAS }}$ ratio where $[\mathrm{X}]_{\text {PAAS }}$ and $\left[\mathrm{Al}_{2} \mathrm{O}_{3}\right]_{\text {PAAS }}$ represent the concentrations of $\mathrm{X}$ and $\mathrm{Al}_{2} \mathrm{O}_{3}$ for PAAS.

Europium anomalies $\left(\mathrm{Eu} / \mathrm{Eu}^{*}\right)$ were calculated according to the following equation:

Equation $2: \quad \mathrm{Eu} / \mathrm{Eu}^{*}=\mathrm{Eu}_{\mathrm{N}} /\left(\mathrm{Sm}_{\mathrm{N}}+\mathrm{Gd}_{\mathrm{N}}\right) / 2$,

where N refers to PAAS-normalized values (Pourmand et al., 2012)

The Al/Si ratio has been shown to be dependent upon particle size in the Amazon Basin. Vertical gradients of the grain-size parameter $\mathrm{D}<90 \mu \mathrm{m}$ and $\mathrm{Al} / \mathrm{Si}$ in the water column are inversely correlated (Bouchez et al., 2011). 
The $\mathrm{Th} / \mathrm{Sc}$ ratio is usually taken as an indicator for igneous differentiation processes (McLennan et al., 1993), while $\mathrm{Cr} / \mathrm{Th}$ ratio can be used to discriminate between "basic" and "silicic" sediments (Cullers, 2000). Fine-grained sediments derived from basic rock sources typically have $\mathrm{Th} / \mathrm{Sc}$ ratios lower than 0.4 and $\mathrm{Cr} / \mathrm{Th}$ higher than 22 . In contrast, fine grained sediments derived from more acidic rock sources display $\mathrm{Th} / \mathrm{Sc}$ ratios higher than 0.64 and Cr/Th ratios lower than 15 (Cullers, 2000).

The Chemical Index of Alteration (CIA) measures the degree of feldspar weathering and the depletion of $\mathrm{Na}^{+}, \mathrm{K}^{+}$and $\mathrm{Ca}^{2+}$ relative to $\mathrm{Al}$, which remains immobile in secondary weathered products (Nesbitt and Young, 1982). It is defined as follows:

Equation $3: \quad \mathrm{CIA}=\left[\mathrm{Al}_{2} \mathrm{O}_{3} /\left(\mathrm{Al}_{2} \mathrm{O}_{3}+\mathrm{CaO} *+\mathrm{Na}_{2} \mathrm{O}+\mathrm{K}_{2} \mathrm{O}\right)\right] \times 100 \quad$ (molar unit) where $\mathrm{CaO}^{*}$ represents the $\mathrm{CaO}$ content in the silicate fraction.

CIA values for unaltered plagioclase and K-feldspars are approximately equal to 50, while sediments with substantial amounts of aluminous clay minerals (such as kaolinite) generally display higher CIA values (between 80-100) (Nesbitt and Young, 1982).

\section{Results}

\subsection{River Discharge and SPM variations}

The Amazon is characterized by maximum and minimum discharges from March to July and October to January, respectively (Figure 3a). During the sampling period, the Amazon discharge ranged from $76500 \mathrm{~m}^{3} . \mathrm{s}^{-1}$ to $260000 \mathrm{~m}^{3} . \mathrm{s}^{-1}$, while SPM concentrations varied from $8 \mathrm{mg} . \mathrm{l}^{-1}$ (July 2012) to $160 \mathrm{mg} . \mathrm{l}^{-1}$ (January 2013), increasing together with discharge in December and then decreasing during sustained high water discharge. The water discharge vs SPM concentration exhibits a clockwise hysteresis behaviour (Martinez et al., 2009).

The Orinoco River exhibits a low water stage from February to April and a high water stage in August (Figure 3B; Laraque et al., 2013b). In 2008, the Orinoco River discharge ranged 
from $4700 \mathrm{~m}^{3} \cdot \mathrm{s}^{-1}$ in April to $7040 \mathrm{~m}^{3} \cdot \mathrm{s}^{-1}$ in August. SPM concentrations were minimal in April during the low discharge period (10 mg. $\left.\mathrm{l}^{-1}\right)$ and maximal in June during the rise of water discharge (160 mg..$\left.^{-1}\right)$. Another SPM maximum (98mg. $\left.\mathrm{l}^{-1}\right)$ occurred in December, as documented in previous studies (Laraque et al., 2013b; Mora et al., 2014).

During the 2008 hydrological cycle, the Maroni River discharge ranged from $280 \mathrm{~m}^{3} \cdot \mathrm{s}^{-1}$ in November to $7010 \mathrm{~m}^{3} . \mathrm{s}^{-1}$ in June (Figure 3C). The highest (36 mg. $\mathrm{l}^{-1}$ ) and lowest $\left(7 \mathrm{mg} . \mathrm{l}^{-1}\right.$ ) SPM concentrations were observed in February and November, respectively, during the periods of high and low water discharges.

\subsection{Mineralogy}

Quartz, mica + illite and kaolinite contents are expressed as a semi-quantitative relative frequency of integrated XRD signals (Table 1). To a first order, SPM from the Amazon and Orinoco Rivers exhibit similar mineral proportions (Figure 4a). In detail, Amazon SPM are slightly depleted in kaolinite and more enriched in mica + illite compared to those of Orinoco. In contrast, the Maroni SPM are almost exclusively composed of kaolinite (Figure 4a). While there is no significant correlation between mineralogical composition and river discharge in the Maroni $\left(\mathrm{R}^{2}<0.42\right)$, the relative abundances of quartz in samples from the Amazon and the Orinoco Rivers (between $20-60 \%$ ) display a significant correlation with SPM concentrations: $\mathrm{R}^{2}=0.87 ; \mathrm{N}=12 ; \mathrm{p}$-value $<0.01$, and $\mathrm{R}^{2}=0.79 ; \mathrm{N}=11 ; \mathrm{p}$-value $<0.01$, respectively (Figure 4b).

\subsection{Major, minor and selected trace elements}

Amazon and Orinoco SPM display very similar PAAS-normalized patterns characterized by relative depletions in $\mathrm{TiO}_{2}, \mathrm{MgO}, \mathrm{Na}_{2} \mathrm{O}, \mathrm{K}_{2} \mathrm{O}, \mathrm{Rb}, \mathrm{Cs}, \mathrm{Zr}, \mathrm{Nb} \mathrm{Cr}$ and $\mathrm{Co}$ (Figures 5a, b). In detail, Orinoco SPM display higher relative abundances of $\mathrm{MgO}, \mathrm{CaO}, \mathrm{Na}_{2} \mathrm{O}, \mathrm{Ba}$ and $\mathrm{Sr}$ and 
lower relative abundances of FeO, Th, U, Y, Zr and Hf. In contrast, Maroni SPM (Figure 5c) have similar relative abundances in $\mathrm{TiO}_{2}, \mathrm{FeO}, \mathrm{MnO}, \mathrm{Sc}$ and $\mathrm{V}$ as those of the Amazon and Orinoco SPM, but are depleted in $\mathrm{SiO}_{2}$ and the differences between mobile and refractory elements are exacerbated (Figure 5d).

In this study, the Amazon and Orinoco SPM (which correspond to particles from surface waters) display quite similar $\mathrm{Al} / \mathrm{Si}$ atomic ratios (mean $\sim 0.47 \pm 0.05$ and $0.40 \pm 0.04$ respectively) (Table 2). These $\mathrm{Al} / \mathrm{Si}$ ratios are much lower than those of the Maroni SPM ( $0.8 \pm 0.04$ ) suggesting that the Amazon and Orinoco exhibit higher mean SPM grain size.

Orinoco SPM showed the highest $\mathrm{Th} / \mathrm{Sc}$ ratios $(0.72-0.97$, mean $\sim 0.85)$ and lowest $\mathrm{Cr} / \mathrm{Th}$ ratios (4.5-7, mean 5.3) (Table 2). For the Amazon SPM, Th/Sc and $\mathrm{Cr} / \mathrm{Th}$ ratios showed intermediate values (Th/Sc: 0.33-0.76, mean; $\sim 0.64$ and $\mathrm{Cr} / \mathrm{Th}: 5.3-7.5$, mean $~ 6.0)$, while Maroni SPM, except for one anomalous sample (MAR06, June), showed overall lower Th/Sc ratios $(0.41-1.25$, mean $\sim 0.60)$ and higher $\mathrm{Cr} / \mathrm{Th}$ ratios $(4.7-18.8$, mean $\sim 12.3)$.

For CIA calculations, neither carbonate leaching nor $\mathrm{CO}_{2}$ analyses were conducted on our samples, so direct correction of carbonate-bound Ca in the studied SPM cannot be quantified. However, based on our mineralogical analyses and previous evidence from Bouchez et al. (2011), we expect the contribution of solid carbonate phases to be negligible at the studied stations, mostly because carbonate-rich sediments issued from the Andes are thought to be rapidly dissolved during river transport. The CIA values for Amazon SPM range from 68 (OB9, September) to 79 (OB13, January). For the Orinoco SPM, CIA values range from 77 (ORI7, July) to 83 (ORI4). The Maroni SPM have the highest CIA values ranging from 87 (MAR4) to 95 (MAR6) (Table 2). Considering the whole dataset the CIA values are negatively correlated with the the mica + illite content $\left(\mathrm{R}^{2}=-0.83\right)$. 


\subsection{Rare Earth Elements (REE)}

REE concentrations are reported in Table 3 and PAAS-normalised REE patterns in Figure 6. Amazon SPM display a slight MREE enrichment $(\mathrm{Gd} / \mathrm{Nd}=1.04 \pm 0.09)$, whereas Orinoco SPM presents a relatively flat pattern. These results are similar to that found by Bayon et al. (2015) for the Amazon and Orinoco clay-size fractions. Maroni SPM presents a LREE enrichment over HREE $(\mathrm{Nd} / \mathrm{Yb}=1.36 \pm 0.19)$. Orinoco, Maroni and Amazon SPM can be distinguished based on their Eu anomalies. The Maroni SPM have the highest Eu/Eu* ratios (1.40-1.64, mean 1.51). The Amazon SPM have Eu/Eu* ratios (1.16-1.39, mean 1.24) higher than those of the Orinoco $(1.03-1.23$, mean $~ 1.14)$. Calculated $\mathrm{Eu} / \mathrm{Eu}^{*}$ ratios for the Amazon and Orinoco clay based on Bayon et al. (2015) dataset yield similar Eu/Eu* ratios (1.20 and 1.07 respectively).

\subsection{Nd and Sr isotopic compositions}

Amazon SPM exhibit $\varepsilon N d$ values ranging from -9.8 (OB11, November) to -11.4 (OB6, June), with ${ }^{87} \mathrm{Sr} /{ }^{86} \mathrm{Sr}$ ratios varying from 0.7173 (OB10, September) to 0.7266 (OB3, March) (Table 3). Compared to the Amazon SPM, the Orinoco SPM display less radiogenic Nd isotopic signatures, with $\varepsilon N d$ values ranging from -13.7 (ORI01 and ORI03 January and March respectively) to -14.6 (ORI09, August), and more radiogenic ${ }^{87} \mathrm{Sr} /{ }^{86} \mathrm{Sr}$ ratios, with values ranging between 0.7257 (ORI03, March) and 0.7306 (ORI11, November). In contrast, the Maroni SPM are characterized by much lower Nd isotopic compositions with $\varepsilon N d$ values ranging from -21 (MAR04, April) to -25.2 (MAR06, June) and slightly higher ${ }^{87} \mathrm{Sr} /{ }^{86} \mathrm{Sr}$ ratios, with values ranging between 0.72954 (MAR04, April) and 0.73611 (MAR03, March). The Sr isotopic composition of analyzed SPM rivers show a strong negative correlation with the mica + illite content $\left(\mathrm{R}^{2}=-0.81\right.$, Figure 7$)$ 


\section{Discussion}

The Amazon, Orinoco and Maroni SPM are characterized by distinct mineralogical compositions, major and trace element concentrations, $\mathrm{Al} / \mathrm{Si}, \mathrm{Eu} / \mathrm{Eu}{ }^{*}, \mathrm{Cr} / \mathrm{Th}, \mathrm{Th} / \mathrm{Sc}$ ratios and Sr-Nd isotopic compositions (Figures 4-7 and Tables 1-3).

Before drawing conclusions on the relative influence of source rock composition and hydrological cycle on the geochemical composition of the SPM, the effect of chemical weathering and grain size sorting must be carefully evaluated as it may control the REE contents and radiogenic isotopes composition of the SPM (Bouchez et al., 2011; Bayon et al., 2015).

The CIA values of the Maroni SPM are substantially higher than those of the Orinoco and Amazon Rivers SPM. In addition, despite a slight overlap (Figure 7), our data shows that the Orinoco SPM have higher CIA values than Amazon SPM (T Test with $\mathrm{P}<0.05$ ). The Amazon CIA values calculated in this study (68-79) are similar to those calculated for Óbidos surface samples based on the dataset of Bouchez et al. (2011) (CIA $=70$ to 77). The contrasts in CIA between the 3 basins could relate to differences in climatic conditions or differences in source rock composition. The Amazon, Orinoco and Maroni river basins are characterized by similar warm and wet climatic conditions, with respective mean annual temperatures of $26.7^{\circ} \mathrm{C}, 23.9$ ${ }^{\circ} \mathrm{C}$ and $26.5^{\circ} \mathrm{C}$, and mean annual precipitation of $2030 \mathrm{~mm} \cdot \mathrm{y}^{-1}, 1400 \mathrm{~mm} \cdot \mathrm{y}^{-1}$ and $2520 \mathrm{~mm} \cdot \mathrm{y}^{-1}$ (Bayon et al., 2016; Sondag et al., 2010). Hence, difference in climatic condition is unlikely to account for both changes in rock weathering intensity and observed variations in the mineralogy and geochemistry of SPM from these river systems.

In addition to climate, grain-size heterogeneity due to hydrological sorting processes in the water column can also lead to geochemical variations between SPM from the investigated tropical South American rivers. As previously shown for the Amazon River (i.e. Bouchez et al., 2011), grain-size of the SPM increases with water depth at Óbidos as Al/Si ratios 
decreases from surface waters $(\sim 0.42)$ to deeper waters $(0.21$ at $55 \mathrm{~m}$ water depth) and bedload sediments (0.08). Our results show that grain size is quite similar for Amazon and Orinoco SPM and present a low annual variability with $\mathrm{Al} / \mathrm{Si}$ standard deviations lower than 10\%. Based on $\mathrm{Al} / \mathrm{Si}$ ratios and kaolinite content, Maroni SPM are significantly finer and have also a lower annual variability ( $\mathrm{Al} / \mathrm{Si}$ standard deviation lower than 5\%; Figure 7). In addition, despite a slight correlation between $\mathrm{Al} / \mathrm{Si}$ and $\mathrm{Eu} / \mathrm{Eu}^{*}$ for the Amazon $\left(\mathrm{R}^{2}=0.51\right.$; $\mathrm{N}=12$; p-value $<0.01$ ) no correlation between $\mathrm{Al} / \mathrm{Si}$ ratios and $\mathrm{Eu} / \mathrm{Eu}^{*}, \mathrm{Cr} / \mathrm{Th}, \mathrm{Th} / \mathrm{Sc}$ and $\mathrm{Sr}-$ $\mathrm{Nd}$ isotopic compositions of SPM is observed in the three basins. As we observe low variations in surface $\mathrm{Al} / \mathrm{Si}$ ratios, no correlation with other variables and previous works showed no significant variations in SPM diameter during the hydrological cycle (Armijos et al., 2017; Bouchez et al., 2011; Pinet et al., 2017), we suggest that the observed mineralogical and geochemical differences are more likely to be controlled by differences in source rock lithology and variations of sedimentary fluxes during the hydrological cycle.

\section{1 Source rock lithology}

\subsubsection{Maroni River}

The Maroni River drains the old weathered Paleoproterozoic terranes of the Guyana shield. Similar igneous/metamorphic terranes from the Guyana shield are also drained by a series of right-bank tributaries of the Orinoco (Aro, Caroni and Caura Rivers) that were recently analysed by Bayon et al. (2015). Both these sediments analysed by Bayon et al. (2015) and the Maroni SPM are dominated by kaolinite (Figures 3 and 6). ${ }^{87} \mathrm{Sr} /{ }^{86} \mathrm{Sr}$ vs. $\varepsilon \mathrm{Nd}$ diagram comparing our data with other relevant data from the literature is presented in Figure 8 . These reference data include various volcanic and sedimentary rocks from the Andes (Barragan et al., 1998; Kay et al., 1994; Pinto, 2003; Rogers and Hawkesworth, 1989) and modern suspended sediments from the Solimões, Madeira and Amazon Rivers (Bouchez et al., 2011; 
Viers et al., 2008). The Maroni SPM display distinctive $\mathrm{Sr}-\mathrm{Nd}$ isotopic compositions compared to the Amazon and Orinoco SPM, characterized by much lower $\varepsilon N d$ values and more radiogenic $\mathrm{Sr}$ isotopic ratios (Figure 8, Table 3). To the best of our knowledge, no $\mathrm{Sr}$ isotopic data exist for river sediments derived from the Guyana shield. However, the $\mathrm{Sr}$ isotopic compositions of the Maroni SPM fall within the range of values reported for the dissolved fraction of the Maroni River $\left({ }^{87} \mathrm{Sr} /{ }^{86} \mathrm{Sr}=0.721-0.734\right.$; Négrel and Lachassagne, 2000 ) and other cratonic rivers in Brazil and Venezuela (Rio Branco: ${ }^{87} \mathrm{Sr} /{ }^{86} \mathrm{Sr}=0.726-0.735$ and Ventuari river: ${ }^{87} \mathrm{Sr} /{ }^{86} \mathrm{Sr}=0.726-0.742$; Edmond et al., 1995). In addition, Maroni SPM have higher $\mathrm{Al} / \mathrm{Si}$ ratios and hence finer grain-size, lower $\mathrm{Th} / \mathrm{Sc}$ ratios, higher $\mathrm{Eu} / \mathrm{Eu} * \mathrm{Cr} / \mathrm{Th}$ and CIA values. All these geochemical and isotopic characteristics indicate that the Maroni River is exporting less differentiated, older and more weathered detritus than those from other analysed tropical South American rivers SPM.

\subsubsection{Orinoco River}

The geochemical and isotopic characteristics of the Orinoco SPM result from the mixing of terrigenous matter delivered from both left- and right-bank tributaries. Left-bank tributaries of the Orinoco River drain various magmatic rocks and sedimentary formations from the Andes, the Caribbean Coastal Range in northern Venezuela and the lowland floodplain. Right-bank tributaries are associated with older and more intensively weathered rocks from the Precambrian Guyana shield. Consequently, the Orinoco SPM have CIA values lower than those of the Maroni and higher than those of the Amazon. The $\mathrm{Th} / \mathrm{Sc}$ and $\mathrm{Cr} / \mathrm{Th}$ ratios indicate that Orinoco SPM are in average the results of the erosion of slightly more differentiated material than Amazon and Maroni SPM. The Orinoco SPM have also distinctive $\mathrm{Sr}-\mathrm{Nd}$ isotopic compositions (Figure 9). While extensive datasets for dissolved ${ }^{87} \mathrm{Sr} /{ }^{86} \mathrm{Sr}$ have been reported earlier (Edmond et al., 1996; Edmond et al., 1995), the only ${ }^{87} \mathrm{Sr} /{ }^{86} \mathrm{Sr}$ isotopic data available for Orinoco sediments $(0.7406 \pm 0.0013, \mathrm{n}=5$; (Parra et al., 1997) are significantly 
more radiogenic than the Orinoco SPM analysed here $\left({ }^{87} \mathrm{Sr} /{ }^{86} \mathrm{Sr}=0.726-0.73\right)$. Measured $\varepsilon N d$ display a narrow range of $\varepsilon \mathrm{Nd}$ values $(-14.1 \pm 0.3)$ in full agreement with the range of values previously reported for other Orinoco river-borne sediments (from -13.6 to -14.1; Goldstein et al., 1997; Parra et al., 1997; Bayon et al., 2015). However the Orinoco SPM \&Nd values are less radiogenic than potential Andean sources (Oriental Cordillera and Subandean zone, Figure 8), and Andean SPM transported by Apure (-11.7) and Meta (-13.4) Rivers (Goldstein et al., 1997). According to Meade (1994), the Apure and Meta Rivers contribute respectively to $17 \%$ and $55 \%$ to the total annual solid discharge from the Orinoco River. The $\varepsilon N d$ signature of SPM transported by the Guaviare River (i.e. a left-bank tributary), which accounts for $23 \%$ of the Orinoco SPM discharge, is yet to be determined. Right bank tributaries of the Orinoco are far less radiogenic with respect to $\varepsilon N d$ (Suapure -19.9; Ventuari20.5; Caura -21.1; Aro -20.1 to -30.7 and Caroni -25.2; Goldstein et al., 1997; Bayon et al., 2015). These tributaries contribute however for less than 5\% of the total annual SPM load. Assuming a constant $\mathrm{Nd}$ concentration in all SPM, a simple mass balance mixing model would require a Guaviare $\varepsilon N d$ value to be comprised between -16 and -14 .

\subsubsection{Amazon River}

Compared to PAAS, the Amazon SPM have slightly higher Eu/Eu* and slightly lower Th/Sc ratios, but higher CIA values indicating that the Amazon SPM are slightly less differentiated and more weathered than PAAS. The $\mathrm{Sr}$ and $\mathrm{Nd}$ isotopic compositions of Amazon SPM measured in this study fall between those reported earlier for the Madeira and Solimões Rivers (Viers et al. 2008) (Figure 8, 9a). Despite significant dispersion in $\varepsilon \mathrm{Nd}$ values for Amazon SPM during the studied hydrological year (between February 2012 and January 2013), the average value $(-10.6 \pm 0.6)$ is similar to that observed for the Amazon at Óbidos in June and October $2013(-10.2 \pm 0.1)$ (Merschel et al., 2017), in the Amazon main channel 
downstream of Madeira confluence ( 7 samples; -10.4 \pm 0.4; Höppner et al., 2018), in the Amazon delta SPM (-10.7 \pm 0.1 ; Rousseau et al. (2015)), and for the Amazon sub-delta sediments $(-10.5 \pm 0.1$; Bayon et al., 2015). Finally, it is in agreement with a previous estimate (-10.3) calculated based on isotopic composition of Madeira and Solimões SPM collected upstream (Viers et al., 2008). Hence, dispersion of the Amazon SPM $\varepsilon N d$ values analysed here may reflect variations in the relative sediment contribution from the Madeira $(\varepsilon N d=-11.5$, Viers et al. 2008) versus Solimões $(\varepsilon N d=-9.5$, Viers et al. 2008) rivers.

\subsection{Influence of the hydrological cycle}

To discuss the influence of the hydrological cycle on SPM geochemistry we investigate the relationship between monthly variations for elemental and isotopic ratios (Figure 9) and parameters such as daily river discharge (Qr), SPM concentrations ([SPM]) and fluxes (Qs) according to equation 4:

\section{Equation 4: Qs= Qr*[SPM]}

;where Qs is the daily SPM flux

\subsubsection{Maroni River}

The following characteristics for the Maroni River exhibit intra-annual variations (Figure 9, Tables 1-3): Al/Si, CIA, Th/Sc, $\mathrm{Cr} / \mathrm{Th},{ }^{87} \mathrm{Sr} /{ }^{86} \mathrm{Sr}$ and $\varepsilon N d$. However, none of these ratios display any correlation with hydrological parameters such as [SPM], Qr or Qs (the highest $\mathrm{R}^{2}$ observed are for $\mathrm{Cr} / \mathrm{Th}$ vs Qr and CIA vs Qr with respective values of 0.41 and 0.35 , all other values being < 0.2 ). This absence of correlation with the hydrological cycle might be due to the fact that absolute variations in SPM concentrations and discharge over the year are much lower for the Maroni (SPMmax-SPMmin $\left.=29 \mathrm{mg} \cdot \mathrm{l}^{-1}\right)$ than for the Amazon and Orinoco $\left(\right.$ SPMmax-SPMmin $=152 \mathrm{mg} . \mathrm{l}^{-1}$ and $148 \mathrm{mg} \cdot \mathrm{l}^{-1}$ respectively) (Figure 9). Despite this general 
lack of correlation, some trends can be observed between $\mathrm{Qr}$ and geochemical and isotopic ratios, especially during the high water discharge peak, when $\mathrm{Cr} / \mathrm{Th}$ and $\varepsilon \mathrm{Nd}$ reach their minimum and $\mathrm{Th} / \mathrm{Sc}$ reaches its maximum value. If we compare $\mathrm{Cr} / \mathrm{Th}$ and $\mathrm{Th} / \mathrm{Sc}$ ratios for the Maroni SPM with those for the Amazon and Orinoco, the Maroni ratios display a higher variability which likely reflects a source effect (Figure 10). Except for 2 samples (January and April), a significant correlation is observed between $\varepsilon N d$ and $\mathrm{Cr} / \mathrm{Th}$ values of SPM transported by the Maroni River (Figure $10, \mathrm{R}^{2}=0.86$ ), which suggests that sediment mixing between "basic" versus more "acidic" sediment sources controls the geochemical composition of the SPM. While the Maroni River basin is dominated by Paleoproterozoic granitic rocks, it also includes basic rocks forming greenstone belts (Gruau et al., 1985). Hence, the observed co-variations between $\varepsilon \mathrm{Nd}$ and $\mathrm{Cr} / \mathrm{Th}$ most likely reflect changes in the relative contribution of granitic versus basic sediment sourced-regions to the total solid load transported by the river. Evidence that the minimum values of $\mathrm{Cr} / \mathrm{Th}$ and $\varepsilon \mathrm{Nd}$ occur in May, June and July (Figure 9c) suggests lower contribution of particles derived from the greenstone belts during that period of increasing rainfall and associated river runoff (Anon, 1975) when the Intertropical Convergence Zone (ITCZ) migrates from its southern to northern position (Carvalho and Oyama, 2013; Marengo, 2004).

\subsubsection{Orinoco River}

Compared to the Maroni, the Orinoco drainage basin covers a much larger area and is characterized by a greater diversity of rock sources and geomorphological settings (i.e. 'young' mountains, sedimentary plain, 'old' cratonic shields). The Orinoco River also displays a particular hydrological regime characterized by relatively high fluctuations of water and sediment discharge and the occurrence of two distinct peaks of SPM concentrations (Figure 9b). 
Despite this particular setting, no correlations of CIA, Th/Sc, $\mathrm{Cr} / \mathrm{Th}, \mathrm{Sr}$ and $\mathrm{Nd}$ isotopic compositions with [SPM], Qr or Qs (the highest $\mathrm{R}^{2}$ observed are for ${ }^{87} \mathrm{Sr} /{ }^{86} \mathrm{Sr}$ vs Qs and Th/Sc vs Qr with respective values of 0.43 and 0.33 are non-significant for $\mathrm{N}=12$ and p-value levels of 0.01 ) is observed (Figure $9 \mathrm{~b}$ and Table $1-3$ ). Moreover, compared with the Maroni SPM, the Orinoco SPM displays lower intra-annual variability of geochemical and isotopic ratios. This is particularly notable for $\mathrm{Nd}$ and $\mathrm{Sr}$ isotopes, suggesting first that Andean sourced sediments are transported all year long to the Ciudad Bolivar station, but also that the geochemical composition of the sediment exported from this area remains relatively homogenous during the hydrological year. The strontium isotopic composition of Orinoco SPM does not fluctuate much over the year, but SPM still display slightly lower ${ }^{87} \mathrm{Sr} /{ }^{86} \mathrm{Sr}$ ratios are $(0.7267 \pm 0.0004)$ between January and April, i.e. during the low water stage, than between May and December $(0.7300 \pm 0.0004)$, when water discharge is increasing (Figure 9). While a similar relationship between discharge and Sr isotopes has also been observed for the Solimões and Madeira Rivers (Viers et al., 2008), the observed SPM geochemical variations in the Orinoco during the year remain quite small, hence suggesting that the Orinoco SPM geochemistry is not controlled by hydrological patterns within the basin.

\subsubsection{Amazon River}

In the Amazon River basin, $\mathrm{Sr}$ isotopic compositions correlate with $\mathrm{Qs}\left(\mathrm{R}^{2}=0.58 ; \mathrm{N}=12\right.$; $\mathrm{p}$ value $<0.01)$ and CIA values correlate with $[\mathrm{SPM}]\left(\mathrm{R}^{2}=0.70 ; \mathrm{N}=12 ; \mathrm{p}\right.$-value $\left.<0.01\right)$. Higher CIA values and more radiogenic $\mathrm{Sr}$ isotopic composition are observed during low water discharge (i.e. during the dry season), a finding that is somehow similar to that found by Viers et al. (2008) for the SPM of the Solimões and Madeira Rivers, the two main Andean tributaries of the Amazon River. 
In contrast with the observations made by Viers et al. (2008) for the Amazon tributaries and by Merschel et al. (2017) for the Amazon at Óbidos, the Nd isotopic compositions display significant seasonal variability, characterized by a gradual $\varepsilon N d$ increase from $-11.4 \pm 0.1$ in June, during the dry season, to $-9.8 \pm 0.2$ in November to January, during the rainy season (Figure 9a). This seasonal contrast is in agreement with Höppner et al. (2018) dataset which show a significant difference between SPM sampled near Óbidos in May $2011(n=2 ;-10.9 \pm$ $0.1)$ and November $2012(\mathrm{n}=2 ;-10.2 \pm 0.1)$. At the studied station (Óbidos), suspended particulates are derived from the mixing of particles from the Andes brought by the Solimões and Madeira Rivers (Bouchez et al., 2011; Viers et al., 2008), together with floodplain sediments, whose geochemical compositions also result from variable relative inputs of Solimões and Madeira SPM (Roddaz et al., 2014). The Nd isotopic composition of the Solimões SPM are more radiogenic than those of the Madeira (Viers et al., 2008). As a consequence, we interpret the observed trend towards more radiogenic $\varepsilon \mathrm{Nd}$ composition most likely results from increasing sediment contributions from the Solimões River.

Bouchez et al. (2011) demonstrated that the Amazon River is stratified, with Madeira and Solimões SPM being preferentially transported near the surface and Solimões SPM near the channel bottom waters, respectively. Presumably, any increase in discharge and turbulent mixing at Óbidos would enhance mixing of Solimões and Madeira SPM and as a consequence probably would lead to favouring the upwelling of more radiogenic in Nd Solimões SPM. However, it is likely that such mixing would also affect the SPM size distribution and lead to variation in $\mathrm{Al} / \mathrm{Si}$ ratios. Likewise, Roddaz et al. (2014) estimated that between $52 \%$ and $100 \%$ of the floodplain deposits proximal to the main channel have low $\mathrm{Al} / \mathrm{Si}$ ratios $(0.15-$ 0.27). If, during the rainy season, increasing bank erosion had favoured the remobilization of such deposits to the Amazon main channel, the observed $\varepsilon N d$ increase should be accompanied by a decrease of $\mathrm{Al} / \mathrm{Si}$ ratios. Instead Amazon SPM at Óbidos has higher $\mathrm{Al} / \mathrm{Si}$ ratios $(0.41-$ 
0.56) and no correlations between $\varepsilon \mathrm{Nd}$ and $\mathrm{Al} / \mathrm{Si}$ values are observed. Consequently, $\varepsilon \mathrm{Nd}$ annual variability in the SPM at Óbidos is unlikely to be controlled by an increase of turbulent mixing condition within the Amazon channel nor by a greater contribution of Amazon floodplain deposits.

To assess the potential control of Madeira versus Solimões Rivers on the observed $\varepsilon N d$ variability at Óbidos, we consider below the rainfall distribution patterns over the Amazon basin. The south-western part of the basin drained by the Madeira River have a marked rainfall seasonality related to South Atlantic Monsoon system (SAMS) activity, it is sensible to the ITCZ migration and mirrors its latitudinal position (Figure 2, 11). In contrast, the western part of the basin drained by the Solimões River experiences a wet climate during the year with moderate precipitation variations. We suggest that the observed $\varepsilon \mathrm{Nd}$ shift between June and November, from Madeira- to Solimões-like compositions, results from seasonal hydroclimate variability across the Amazon Basin. In this case, however, a significant lag in the propagation of the hydrological signal between the Andes and Óbidos needs to be considered as this period corresponds to an increase in rainfall over the upper Madeira region. Such a lag can be difficult to assess over long distances. For example hydrological stations located about $500 \mathrm{~km}$ upstream from Óbidos on the Madeira and Solimões Rivers can present a 10-14 days delay in the discharge signal (Mangiarotti et al., 2013). By analogy, and considering the $>2000 \mathrm{~km}$ distance that separates Óbidos station to the upstream Andean source regions, a three to four-month delay of the ITCZ latitudinal signal would match well with our $\varepsilon N d$ SPM signal at Óbidos, hence suggesting that this hypothesis is plausible (Figure 11). Following this scenario, the observed $\varepsilon N d$ Amazon SPM from May to June is dominated by Madeira $\varepsilon N d$ SPM signature, from November to January by Solimões one and from July to October by a mix of Solimões and Madeira. 


\subsection{Implication for paleoclimate reconstruction}

As shown above, suspended matter from the Maroni, the Orinoco and the Amazon (including Solimões and Madeira catchment areas) river basins all display contrasted $\varepsilon \mathrm{Nd}$ values and ${ }^{87} \mathrm{Sr} /{ }^{86} \mathrm{Sr}$ isotopic compositions that can be used to trace the origin of the lithogenic material deposited on adjacent ocean margins. In addition, the $\mathrm{Sr}$ and $\mathrm{Nd}$ isotopic compositions of analysed SPM may provide interesting constraints on sediment provenance changes related to spatio-temporal variations of rainfall (especially linked to migrations of the tropical rainbelt).

For large rivers such as the Amazon and the Orinoco, the [SPM]-Qr relationship is not straightforward at their outlets due to the hysteresis behaviour caused by a difference in SPM concentrations during the increase and decrease of the river discharge. The amount of sediment exported monthly (Qs) is however mainly controlled by the intensity of precipitation over the Andean part of their hydrographic basin (Armijos et al., 2013a; Armijos et al., $2013 b$ ), in addition to other internal sedimentary processes that may take place in the floodplain areas (Dunne et al., 1998; Meade et al., 1985; Santini et al., 2015; Vauchel et al., 2017). Although specific hydrological processes in the floodplains may alter the univocal [SPM]-Qr relationship through dilution effect and various sedimentary effects (Bourgoin et al., 2007; Santini et al., 2015; Vauchel et al., 2017), the geochemistry of exported SPM is mainly controlled by the relative sediment contribution (and consequently rainfall distribution) from the upstream source regions. Hence, if preserved in sedimentary archives, these distinct geochemical signatures may be used to reconstruct past rainfall distribution in the source region.

Erosional patterns and, by inference, rainfall distribution have been reconstructed using $\mathrm{Sr}-$ $\mathrm{Nd}$ isotopic composition of past sediments, wherever potential provenance areas display 
marked geochemical compositions (e.g.(Chiessi et al., 2009; Hu et al., 2004). Based on major element compositions of late Quaternary marine sediment, Govin et al. (2014) suggested that the relative proportion of Andean versus lowland sediments increased during periods of high austral summer insolation, in agreement with findings from speleothem records (Cheng et al., 2013; Cruz et al., 2009; Mosblech et al., 2012). Similar changes in sediment provenance between Andes and shield regions were also inferred using $\mathrm{Nd}-\mathrm{Sr}$ isotopic composition of marine sediments from the Guyana continental slope (Höppner et al., 2018). Our new set of Sr-Nd isotopic data reinforce the view that these proxies can be used in Quaternary sediment archives stored along the tropical South American continental margin for reconstructing the erosional and associated rainfall patterns on continental source regions through time (e.g. Höppner et al., 2018; Zhang et al., 2015). However care must be taken using Sr isotopes for paleoclimate reconstructions as they display a high variability throughout the hydrological cycle. Such variability might be caused by increasing contribution of Sr-rich and Nd-Poor micas during the rainy season that could explain as the observed correlations between mica + illite and Sr isotopic composition (Figure 7). A similar explanation (i.e. contribution of Sr rich and Nd-poor micas) has been proposed to explain the decoupling between $\mathrm{Sr}$ and $\mathrm{Nd}$ isotopic composition of marine core sediments from the slope off French Guiana that recorded the last 40 kyr of Amazon River SPM (Höppner et al., 2018) .

In this context, the extensive data set presented in our study may provide additional new constraints on sediment provenance that can be used to further discriminate between the various Andean and cratonic sediment source regions (Govin et al., 2014; Höppner et al., 2018) and complement previous paleoclimatic studies conducted on lake sediment records (Baker et al., 2001a; Baker et al., 2001b; Fritz et al., 2007). 


\section{Conclusions}

Our detailed mineralogical and geochemical investigation of SPM transported by the Amazon, Orinoco and Maroni Rivers over a one-year hydrological cycle allowed us to identify distinctive geochemical signatures exported by each of these three basins. These signatures reflect differences in source rock lithology from their corresponding watersheds and their variability are controlled by the annual hydrological cycles. In details:

- The Maroni SPM have higher Al/Si ratios and hence finer grain-size, lower $\mathrm{Th} / \mathrm{Sc}$ ratios and $\varepsilon \mathrm{Nd}$ values $(-23.7 \pm 1.2)$ higher $\mathrm{Cr} / \mathrm{Th}$, CIA values and $\mathrm{Sr}$ isotopic composition when compared with other analysed SPM indicating the Maroni River is exporting less differentiated, older and more weathered detritus than those from other analysed tropical South American rivers SPM. $\varepsilon N d$ and Cr/Th covariation for Maroni SPM during the hydrological cycle reflect the change in relative contribution of greenstone belt and Paleoproterozoic granitic rocks associated with rainfall distribution heterogeneities linked to ICTZ migration.

- The Orinoco SPM are characterized by distinct CIA values, $\mathrm{Th} / \mathrm{Sc}$ and $\mathrm{Cr} / \mathrm{Th}$ and $\mathrm{Sr}-$ $\mathrm{Nd}$ isotopic compositions $(0.7288 \pm 0.0018$ and $\varepsilon \mathrm{Nd}=-14.1 \pm 0.3$, respectively). There is no control of the hydrogical cycle on the geochemistry of Orinoco SPM.

- The Amazon SPM have distinct $\mathrm{Th} / \mathrm{Sc}$ ratios, CIA values and $\mathrm{Sr}-\mathrm{Nd}$ isotopic compositions indicating that the Amazon SPM are slightly less differentiated and more weathered than PAAS. The Sr and Nd isotopic compositions of Amazon SPM range between those of the Madeira and Solimões SPM. The Amazon SPM are characterized by significant $\mathrm{Sr}$ isotope annual variability (with associated mean and standard deviation of $0.7213 \pm 0.0030$ ) correlated with suspended sediments discharge. We also demonstrate a small but significant $\mathrm{Nd}$ isotopic variability over the year (with associated mean and standard deviation of $-10.6 \pm 0.6$ ), from a Madeira- to Solimões- 
like composition. We relate this variability to seasonal changes in the rainfall distribution patterns across the Amazon basin, associated with latitudinal migrations of the ITCZ.

Consequently, the $\mathrm{Nd}$ isotopic composition of past fine-grained sediments deposited on adjacent ocean margins could be used as a proxy for reconstructing past hydroclimate changes over tropical South America, more specifically, to infer the past position of the tropical rain belt and the ITCZ through time.

\section{Acknowledgements}

This research was funded by Instituts Carnot ISI-FOR and EDROME. This research was supported by the French Research Institute for Development (IRD), by the HyBAm Observatory (Hydrology and Geochemistry of the Amazon Basin, www.mpl.ird.fr/hybam/) in the framework of its cooperation agreement with the Brazilian Research Centre (CNPq process nos. 492685/2004-05 and 690139/2003-09). We thank the two anonymous reviewers and editor are thanked for their constructive reviews.

\section{References}

Aalto, R., Dunne, T., Guyot, J.-L., 2006. Geomorphic Controls on Andean Denudation Rates. The Journal of Geology, 114(1): 85-99.

Abbey, S., 1980. Studies in "Standard Samples" for use in the general analysis of silicate rocks and minerals. Geostandards and Geoanalytical Research, 4(2): 163-190.

Ahlfeld, F., Branisa, L., 1960. Geología de Bolivia. Editorial Don Bosco. Allègre, C.J., Dupré, B., Négrel, P., Gaillardet, J., 1996. $\mathrm{Sr}-\mathrm{Nd}-\mathrm{Pb}$ isotope systematics in Amazon and Congo River systems: constraints about erosion processes. Chemical Geology, 131(1-4): 93-112.

Anon, 1975. Climatologie de la Guyane. . Contrib. scient. ORSTOM, Tome Secrétariat d'Etat aux D.O.M. - T.O.M., doc mult: 41 - 59.

Aries, S., Valladon, M., Polvé, M., Dupré, B., 2000. A Routine Method for Oxide and Hydroxide Interference Corrections in ICP-MS Chemical Analysis of Environmental and Geological Samples. Journal of Geostandards and Geoanalysis, 24(1): 19 - 31

Armijos, E., Crave, A., Espinoza, R.,Fraizy, P.,Dos Santos, A.L.M.R., Sampaio, F., De Oliveira, E., Santini, W., Martinez, J.M., Autin, P, 2017. Measuring and modeling vertical gradients in suspended sediments in the Solimões/Amazon River. Hydrological Processes, 31(3): 654-667.

Armijos, E., Crave, A., Vauchel, P., Fraizy, P., Santini, W., Moquet, J-S., Arevalo, N., Carranza, J., Guyot, J-L., 2013a. Suspended sediment dynamics in the Amazon River of Peru. Journal of South American Earth Sciences, 44: 75-84. 
Armijos, E., Laraque, A., Barba, S., Bourrel, L., Ceron, C., Lagane, C., Magat, P., Moquet, JS., Pombosa, R., Sondag, F., 2013b. Yields of suspended sediment and dissolved solids from the Andean basins of Ecuador. Hydrological Sciences Journal, 58(7): 1478-1494.

Baker, P.A., Rigsby, C.A. Seltzer, G.O., Fritz, S.C., Lowenstein, T.K., Bacher, N.P., Veliz, C., 2001a. Tropical climate changes at millennial and orbital timescales on the Bolivian Altiplano. Nature, 409(6821): 698.

Baker, P.A., Seltzer, G. O., Fritz, S. C., Dunbar, R.B., Grove, M. J. Tapia, P.M., Cross, S.L., Rowe, H.D., Broda, J.P., 2001b. The history of South American tropical precipitation for the past 25,000 years. Science, 291(5504): 640-643.

Baldock, J.W., 1982. Geología del Ecuador, Boletín de Explicación del Mapa Geológico dela Republica del Ecuador al 1:1 000 000. Quito Ecuador.

Barragan, R., Geist, D., Hall, M., Larson, P., Kurz, M., 1998. Subduction controls on the compositions of lavas from the Ecuadorian Andes. Earth Planet. Sci. Lett., 154: 153166.

Basu, A.R., Sharma, M., DeCelles, P.G., 1990. Nd, Sr-isotopic provenance and trace element geochemistry of Amazonian foreland basin fluvial sands, Bolivia and Peru: implications for ensialic Andean orogeny. Earth and Planetary Science Letters, 100(13): 1-17.

Bayon, G.,Skonieczny, C., Delvigne, C., Toucanne, S., Bermell, S., Ponzevera, E., Andre, L., 2016. Environmental $\mathrm{Hf}-\mathrm{Nd}$ isotopic decoupling in World river clays. Earth and Planetary Science Letters, 438: 25-36.

Bayon, G., Toucanne, S., Skonieczny, C., André, L., Bermell, S., Cheron, S., Dennielou, B., Etoubleau, J., Freslon, N., Gauchery, T., Germain, Y., Jorry, S. J., Ménot, G., Monin, L., Ponzevera, E., Rouget, M. L., Tachikawa, K., Barrat, J. A., 2015. Rare earth elements and neodymium isotopes in world river sediments revisited. Geochimica et Cosmochimica Acta, 170: 17-38.

Bonnet, M.P., Barroux, G., Martinez, J. M., Seyler, F., Moreira-Turcq, P., Cochonneau, G., Melack, J. M., Boaventura, G., Maurice-Bourgoin, L., Leon, J.G., Roux, E., Calmant, S., Kosuth, P., Guyot, J. L., Seyler, P.,, 2008. Floodplain hydrology in an Amazon floodplain lake (Lago Grande de Curuai). Journal of Hydrology, 349(1-2): 18-30.

Bouchez, J., Gaillardet, J., France-Lanord, C., Maurice, L., Dutra-Maia, P., 2011. Grain size control of river suspended sediment geochemistry: Clues from Amazon River depth profiles. Geochemistry, Geophysics, Geosystems, 12(3): Q03008.

Bouchez, J., Moquet, J-S, Espinoza, J. C., Martinez, J-M., Guyot, J-L., Lagane, C., Filizola, N., Noriega, L., Hidalgo Sanchez, L., Pombosa, R., 2017. River mixing in the Amazon as a driver of concentration- discharge relationships. Water Resources Research, 53(11): 8660-8685.

Bourgoin, L.M. et al., 2007. Temporal dynamics of water and sediment exchanges between the Curuaí floodplain and the Amazon River, Brazil. Journal of Hydrology, 335(1): 140-156.

Callède, J., Cochonneau, J., Ronchail, F., Vieira Alvez, J., Guyot, J-L., Guimarães V. S., Olivera, E. de., 2010. Les apports en eau de l'Amazone à l'Océan Atlantique. Revue des sciences de l'eau/Journal of Water Science, 23(3): 247-273.

Carvalho, M.Â.V.d., Oyama, M.D., 2013. Variabilidade da largura e intensidade da Zona de Convergência Intertropical atlântica: aspectos observacionais. Revista Brasileira de meteorología, 28: 305-316.

Cheng, H., Sinha, A., Cruz, Francisco W., Wang, X., Edwards, R L., d'Horta, F.M., Ribas, C.C., Vuille, M., Stott, L.D., Auler, A.S., 2013. Climate change patterns in Amazonia and biodiversity. Nature communications, 4: 1411. 
Chiessi, C.M., Mulitza, S., Pätzold, J., Wefer, G., Marengo, J.A., 2009. Possible impact of the Atlantic Multidecadal Oscillation on the South American summer monsoon. Geophysical Research Letters, 36(21).

Cruz, F.W., Vuille, M., Burns, Stephen J., Wang, X., Cheng, H., Werner, M., Edwards, R.L., Karmann, I., Auler, A.S., Nguyen, H., 2009. Orbitally driven east-west antiphasing of South American precipitation. Nature Geoscience, 2(3): 210.

Cullers, R.L., 2000. The geochemistry of shales, siltstones and sandstones of PennsylvanianPermian age, Colorado, USA: implications for provenance and metamorphic studies. Lithos, 51(3): 181-203.

Dai, A., Trenberth, K.E., 2002. Estimates of freshwater discharge from continents: Latitudinal and seasonal variations. Journal of hydrometeorology, 3(6): 660-687.

Dosseto, A., Bourdon, B., Gaillardet, J., Allègre, C.J., Filizola, N., 2006. Time scale and conditions of weathering under tropical climate: Study of the Amazon basin with Useries. Geochimica Et Cosmochimica Acta, 70(1): 71-89.

Dunne, T., Mertes, L.A., Meade, R.H., Richey, J.E., Forsberg, B.R., 1998. Exchanges of sediment between the flood plain and channel of the Amazon River in Brazil. Geological Society of America Bulletin, 110(4): 450-467.

Edmond, J., Palmer, M., Brown, E., Huh, Y., 1996. Fluvial geochemistry of the eastern slope of the northeastern Andes and its foredeep in the drainage of the Orinoco in Colombia and Venezuela. Geochimica et Cosmochimica Acta, 60(16): 2949-2974.

Edmond, J., Palmer, M., Measures, C., Grant, B., Stallard, R., 1995. The fluvial geochemistry and denudation rate of the Guayana Shield in Venezuela, Colombia, and Brazil. Geochimica et Cosmochimica Acta, 59(16): 3301-3325.

Espinoza Villar, J.C., Ronchail, J., Guyot, J-L., Cochonneau, G., Naziano, F., Lavado, W., De Oliveira, E., Pombosa, R., Vauchel, P., 2009. Spatio- temporal rainfall variability in the Amazon basin countries (Brazil, Peru, Bolivia, Colombia, and Ecuador). International Journal of Climatology, 29(11): 1574-1594.

Filizola, N., Guyot, J.-L., 2004. The Use of Doppler Technology for Suspended Sediment Discharge Determination in the Amazon River. Hydrological Sciences Journal of Environmental Monitoring, 49(1): 143-153.

Filizola, N., Guyot, J.-L., Wittmann, H., Martinez, J.-M., de Oliveira, E., 2011. The significance of suspended sediment transport determination on the Amazonian hydrological scenario, Sediment transport in aquatic environments. InTech.

Filizola, N., Guyot, J.L., 2009. Suspended sediment yields in the Amazon basin: an assessment using the Brazilian national data set. Hydrological Processes: An International Journal, 23(22): 3207-3215.

Fritz, S.C., Baker, P.A., Seltzer, G.O., Ballantyne, A., Tapia, P., Cheng, H., Edwards, R. L., 2007. Quaternary glaciation and hydrologic variation in the South American tropics as reconstructed from the Lake Titicaca drilling project. Quaternary Research, 68(3): 410-420.

Furch, K., Junk, W., 1982. Seasonal nutrient dynamics in aAmazonian floodplain lake. Arch. Hydrobiol, 128(3): 227-285.

Gaillardet, J., Dupre, B., Allegre, C.J., 1999. Geochemistry of large river suspended sediments: Silicate weathering or recycling tracer? Geochimica Et Cosmochimica Acta, 63(23-24): 4037-4051.

Gaillardet, J., Dupre, B., Allègre, C.J., Négrel, P., 1997. Chemical and physical denudation in the Amazon River Basin. Chemical Geology, 142(3-4): 141-173.

Galy, V., France-Lanord, C., Beyssac, O., Faure, P., Kudrass, H., Palhol, F., 2007. Efficient organic carbon burial in the Bengal fan sustained by the Himalayan erosional system. Nature, 450(7168): 407-U6. 
Gibbs, R.J., 1967. The Geochemistry of the Amazon River System: Part I. The Factors that Control the Salinity and the Composition and Concentration of the Suspended Solids. Geological Society of America Bulletin, 78(10): 1203-1232.

Goldstein, S., Arndt, N., Stallard, R., 1997. The history of a continent from U-Pb ages of zircons from Orinoco River sand and $\mathrm{Sm}-\mathrm{Nd}$ isotopes in Orinoco basin river sediments. Chemical Geology, 139(1-4): 271-286.

Goldstein, S.J., Jacobsen, S.B., 1988. Nd and Sr isotopic systematics of river water suspended material: implications for crustal evolution. Earth and Planetary Science Letters, 87(3): 249-265.

Goldstein, S.L., O'Nions, R.K., Hamilton, P.J., 1984. A Sm-Nd isotopic study of atmospheric dusts and particulates from major river systems. Earth and Planetary Science Letters, 70(2): 221-236.

Govin, A., Chiessi, C. M., Zabel, M., Sawakuchi, A.O., Heslop, D., Hörner, T., Zhang, Y., Mulitza, S., 2014. Terrigenous input off northern South America driven by changes in Amazonian climate and the North Brazil Current retroflection during the last $250 \mathrm{ka}$. Climate of the Past, 10(2): 843-862.

Gruau, G., Martin, H., Leveque, B., Capdevila, R., Marot, A., 1985. Rb-Sr and Sm-Nd geochronology of lower Proterozoic granite-greenstone terrains in French Guiana, South America. Precambrian Research, 30(1): 63-80.

Guimberteau, M., Drapeau, G., Ronchail, J., Sultan, B., Polcher, J., Martinez, J-M., Prigent, C., Guyot, J-L, Cochonneau, G., Espinoza Villar, J.C., 2012. Discharge simulation in the sub-basins of the Amazon using ORCHIDEE forced by new datasets. Hydrology and Earth System Sciences, 16(3): 11171-11232.

Guyot, J.L., Filizola, N., Laraque, A., 2005. The suspended sediment flux of the River Aazon at Obidos, Brazil, 1995-2003. In: Walling, D.E., Horowitz, A.J. (Eds.), Sediment Budgets 1. Iahs Publication, pp. 347-354.

Guyot, J.L., Jouanneau, J. M., Soares, L., Boaventura, G. R., Maillet, N., Lagane, C., 2007. Clay mineral composition of river sediments in the Amazon Basin. Catena, 71(2): 340-356.

Guyot, J.L., Jouanneau, J.M., Wasson, J.G., 1999. Characterisation of river bed and suspended sediments in the Rio Madeira drainage basin (Bolivian Amazonia). Journal of South American Earth Sciences, 12(4): 401-410.

Hamilton, S.K., 2010. Biogeochemical implications of climate change for tropical rivers and floodplains. Hydrobiologia, 657(1): 19-35.

Hodell, D.A., Kamenov, G.D., Hathorne, E.C., Zachos, J.C., Röhl, U., Westerhold, T., 2007. Variations in the strontium isotope composition of seawater during the Paleocene and early Eocene from ODP Leg 208 (Walvis Ridge). Geochemistry, Geophysics, Geosystems, 8(9):

Hoorn, C., Bogotá-A, G.R., Romero-Baez, M., Lammertsma, E.I., Flantua, S.G.A., Dantas, E.L., Dino, R., do Carmo, D.A., Chemale, F., 2017. The Amazon at sea: Onset and stages of the Amazon River from a marine record, with special reference to Neogene plant turnover in the drainage basin. Global and Planetary Change, 153: 51-65.

Höppner, N., Lucassen, F., Chiessi, C.M., Sawakuchi, A.O., Kasemann, S.A., 2018. Holocene provenance shift of suspended particulate matter in the Amazon River basin. Quaternary Science Reviews, 190: 66-80.

Hu, C., Montgomery, E.T., Schmitt, R.W., Muller-Karger, F.E., 2004. The dispersal of the Amazon and Orinoco River water in the tropical Atlantic and Caribbean Sea: Observation from space and S-PALACE floats. Deep Sea Research Part II: Topical Studies in Oceanography, 51(10-11): 1151-1171. 
INGEMMET, 1999. Geological Maps, Scale 1:100, 000. . INGEMMET-Instituto Geologico y Metalurgico del Peru, Lima, Peru.

Jacobsen, S.B., Wasserburg, G.J., 1980. Sm-Nd isotopic evolution of chondrites. Earth and Planetary Science Letters, 50(1): 139-155.

Junk, W., Sioli, H., 1984. The Amazon: Limnology and Landscape Ecology of a Mighty Tropical River and its Basin 264.

Kay, S., Coira, B., Viramonte, J., 1994. Young mafic back arc volcanic rocks as indicators of continental lithospheric delamination beneath the Argentina Puna plateau, central Andes. J. Geophys. Res., 99: 24323-24339.

Konhauser, K.O., Fyfe, W.S., Kronberg, B.I., 1994. Multi-element chemistry of some Amazonian waters and soils. Chemical Geology, 111(1-4): 155-175.

Laraque, A., Castellanos, B., Steiger, J., Lòpez, J.L., Pandi, A., Rodriguez, M., Rosales, J., Adèle, G., Perez, J., Lagane, C., 2013a. A comparison of the suspended and dissolved matter dynamics of two large inter-tropical rivers draining into the Atlantic Ocean: the Congo and the Orinoco. Hydrological Processes, 27(15): 2153-2170.

Laraque, A., Moquet, J-S., Alkattan, R., Steiger, J., Mora, A., Adèle, G., Castellanos, B., Lagane, C., Lopez, José L., Perez, J., Rodriguez, M., Rosales, J., 2013b. Seasonal variability of total dissolved fluxes and origin of major dissolved elements within a large tropical river: The Orinoco, Venezuela. Journal of South American Earth Sciences, 44: 4-17.

Lugmair, G.W., Shimamura, T., Lewis, R.S., Anders, E., 1983. Samarium-146 in the Early Solar System: Evidence from Neodymium in the Allende Meteorite. Science, 222(4627): 1015-1018.

Mangiarotti, S., Martinez, J-M., Bonnet, M-P., Buarque, D.C., Filizola, N., Mazzega, P., 2013. Discharge and suspended sediment flux estimated along the mainstream of the Amazon and the Madeira Rivers (from in situ and MODIS Satellite Data). International Journal of Applied Earth Observation and Geoinformation, 21: 341-355..

Marengo, J., 2004. Interdecadal variability and trends of rainfall across the Amazon basin. Theoretical and applied climatology, 78(1): 79-96.

Marengo, J., Liebmann, B., Grimm, A.M., Misra, V., Silva Dias, P.L., Cavalcanti, I.F.A., Carvalho, L.M.V., Berbery, E.H., Ambrizzi, T., Vera, C.S., 2012. Recent developments on the South American monsoon system. International Journal of Climatology, 32(1): 1-21.

Martinelli, L.A., Victoria, R.L., Dematte, J.L.I., Richey, J.E., Devol, A.H., 1993. Chemical and mineralogical composition of Amazon River floodplain sediments, Brazil. Applied Geochemistry, 8(4): 391-402.

Martinez, J.M., Guyot, J.L., Filizola, N., Sondag, F., 2009. Increase in suspended sediment discharge of the Amazon River assessed by monitoring network and satellite data. Catena, 79(3): 257-264.

Martinez, J.M., Le Toan, T., 2007. Mapping of flood dynamics and spatial distribution of vegetation in the Amazon floodplain using multitemporal SAR data. /Remote Sensing of Environment. 108: 209-223, .

McLennan, S., Hemming, S., McDaniel, D., Hanson, G., 1993. Geochemical approaches to sedimentation, provenance, and tectonics. Geological Society of America Special Papers, 284: 21-40.

Meade, R.H., 1994. Suspended sediments of the modern Amazon and Orinoco rivers. Quaternary International, 21(0): 29-39.

Meade, R.H., Dunne, T., Richey, J.E., Santos, U.D.M., Salati, E., 1985. Storage and remobilization of suspended sediment in the lower amazon river of Brazil. Science, 228: 488-490. 
Merschel, G., Bau, M., Schmidt, K., Münker, C., Dantas, E.L., 2017. Hafnium and neodymium isotopes and REY distribution in the truly dissolved, nanoparticulate/colloidal and suspended loads of rivers in the Amazon Basin, Brazil. Geochimica et Cosmochimica Acta.

Mertes, L.A., Dunne, T., Martinelli, L.A., 1996. Channel-floodplain geomorphology along the Solimões-Amazon river, Brazil. Geological Society of America Bulletin, 108(9): 1089-1107.

Meybeck, M., 1993. Riverine Transport of Atmospheric Carbon - Sources, Global Typology and Budget. Water Air and Soil Pollution, 70(1-4): 443-463.

Milliman, J., Farnsworth, K., 2011a. Runoff, erosion, and delivery to the coastal ocean. River discharge to the coastal ocean: a global synthesis, Cambridge University Press, Cambridge, UK: 13-69.

Milliman, J.D., Farnsworth, K.L., 2011b. River Discharge to the Coastal Ocean. A Global Synthesis. Cambridge University Press

Milliman, J.D., Meade, R.H., 1983. World-wide dlivery of river sediment to the oceans. J.Geol., 91: 1-21.

Molina-Carpio, J., Espinoza, J.C., Vauchel, P., Ronchail, J., Gutierrez Caloir, B., Guyot, J-L. Noriega, Luis et al., 2017. Hydroclimatology of the Upper Madeira River basin: spatio-temporal variability and trends. Hydrological Sciences Journal, 62(6): 911-927.

Moquet, J.-S., Guyot, J-L., Crave, A., Viers, J., Filizola, N., Martinez, J-M., Oliveira, T.C. Sánchez, L.S.H., Lagane, C., Casimiro, W.S.L., 2016. Amazon River dissolved load: temporal dynamics and annual budget from the Andes to the ocean. Environmental Science and Pollution Research, 23(12): 11405-11429.

Mora, A., Laraque, A., Moreira-Turcq, P., Alfonso, J.A., 2014. Temporal variation and fluxes of dissolved and particulate organic carbon in the Apure, Caura and Orinoco rivers, Venezuela. Journal of South American Earth Sciences, 54: 47-56.

Mosblech, N.A., Bush, M.B., Gosling, W.D., Hodell, D., Thomas, L., Van Calsteren, P., Correa-Metrio, A., Valencia, B.G., Curtis, J., Van Woesik, R., 2012. North Atlantic forcing of Amazonian precipitation during the last ice age. Nature Geoscience, 5(11): 817.

Négrel, P., Lachassagne, P., 2000. Geochemistry of the Maroni River (French Guiana) during the low water stage: implications for water-rock interaction and groundwater characteristics. Journal of Hydrology, 237(3): 212-233.

Nesbitt, H., Young, G., 1982. Early Proterozoic climates and plate motions inferred from major element chemistry of lutites. Nature, 299(5885): 715-717.

Parra, M., Faugères, J.-C., Grousset, F., Pujol, C., 1997. Sr-Nd isotopes as tracers of finegrained detrital sediments: the South-Barbados accretionary prism during the last 150 kyr. Marine Geology, 136(3-4): 225-243.

Pinet, S., Martinez, J.-M., Ouillon, S., Lartiges, B., Villar, R.E., 2017. Variability of apparent and inherent optical properties of sediment-laden waters in large river basins-lessons from in situ measurements and bio-optical modeling. Optics Express, 25(8): A283A310.

Pinto, L., 2003. Traçage de l'érosion Cénozoïque des Andes Centrales à l'aide dela minéralogie et de la géochmie des sédiements (Nord du Chili et Nord-Ouest de la Bolivie). PhD Thesis, University Paul Sabatier, Toulouse, 196 pp.

Pourmand, A., Dauphas, N., Ireland, T.J., 2012. A novel extraction chromatography and MCICP-MS technique for rapid analysis of REE, Sc and Y: Revising CI-chondrite and Post-Archean Australian Shale (PAAS) abundances. Chemical Geology, 291: 38-54.

Raia, A., Cavalcanti, I.F.A., 2008. The life cycle of the South American monsoon system. Journal of Climate, 21(23): 6227-6246. 
Roddaz, M., Viers, J., Brusset, S., Baby, P., Hérail, G., 2005. Sediment provenances and drainage evolution of the Neogene Amazonian foreland basin. Earth and Planetary Science Letters, 239(1-2): 57-78.

Roddaz, M., Viers, J., Moreira-Turcq, P., Blondel, C., Sondag, F., Guyot, J-L., Moreira, L., 2014. Evidence for the control of the geochemistry of Amazonian floodplain sediments by stratification of suspended sediments in the Amazon. Chemical Geology, 387: 101-110.

Roddaz, M., Viers, J., Brusset, S., Baby, P., Boucayrand, C., Hérail, G., 2006. Controls on weathering and provenance in the Amazonian foreland basin: Insights from major and trace element geochemistry of Neogene Amazonian sediments. Chemical Geology, 226(1â€"2): 31-65.

Rogers, G., Hawkesworth, C.J., 1989. A geochemical traverse across the North Chilean Andes: evidence for crust generation from the mantle wedge. Earth Planet. Sci. Lett., 91: 271-275.

Rousseau, T.C.C., Sonke, J.E., Chmeleff, J., van Beek, P., Souhaut, M., Boaventura, G. Seyler, P., Jeandel, C., 2015. Rapid neodymium release to marine waters from lithogenic sediments in the Amazon estuary. Nature communications, 6: 7592.

Santini, W., Martinez, J-M., Espinoza-Villar, R., Cochonneau, G., Vauchel, P., Moquet, J-S., Baby, P., Espinoza, J-C., Lavado, W., Carranza, J., 2015. Sediment budget in the Ucayali River basin, an Andean tributary of the Amazon River. Proceedings of the International Association of Hydrological Sciences, 367: 320.

Sawakuchi,, Jain, M., Mineli, T.D., Nogueira, L., Bertassoli, D.J., Häggi, C., Sawakuchi, H.O., Pupim, F.N., Grohmann, C.H., Chiessi, C.M., 2018. Luminescence of quartz and feldspar fingerprints provenance and correlates with the source area denudation in the Amazon River basin. Earth and Planetary Science Letters, 492: 152-162.

SERGEOMIN and YPFB, 2000. Mapa geológico de Bolivia, Esc. 1:1.000.000. S.N.d.G.y.Minería-(SERGEOMIN) and Y.P.F.B. (YPFB) (Editors), La Paz.

Sondag, F., Guyot, J-L., Moquet, J-S., Laraque, A., Adele, G., Cochonneau, G., Doudou, J-C., Lagane, C., Vauchel, P., , 2010. Suspended sediment and dissolved load budgets of two Amazonian rivers from the Guiana Shield: Maroni River at Langa Tabiki and Oyapock River at Saut Maripa (French Guiana). Hydrological Processes, 24(11): 1433-1445.

Syvitski, J.P., Cohen, S., Kettner, A.J., Brakenridge, G.R., 2014. How important and different are tropical rivers? - An overview. Geomorphology, 227: 5-17.

Syvitski, J.P., Milliman, J.D., 2007. Geology, geography, and humans battle for dominance over the delivery of fluvial sediment to the coastal ocean. The Journal of Geology, 115(1): 1-19.

Syvitski, J.P., Peckham, S.D., Hilberman, R., Mulder, T., 2003. Predicting the terrestrial flux of sediment to the global ocean: a planetary perspective. Sedimentary Geology, 162(1): 5-24.

van Soelen, E.E. et al., 2017. A 30 Ma history of the Amazon River inferred from terrigenous sediments and organic matter on the Ceará Rise. Earth and Planetary Science Letters, 474: 40-48.

Vauchel, P., Santini, W., Guyot, J-L., Moquet, J-S., Martinez, J-M., Espinoza, J.C., Baby, P., Fuertes, O., Noriega, L., Puita, O., , 2017. A reassessment of the suspended sediment load in the Madeira River basin from the Andes of Peru and Bolivia to the Amazon River in Brazil, based on 10 years of data from the HYBAM monitoring programme. Journal of Hydrology, 553: 35-48.

Viers, J., Barroux, G., Pinelli, M., Seyler, P., Oliva, P., Dupré, B., Boaventura, G.R., 2005. The influence of the Amazonian floodplain ecosystems on the trace element dynamics 
of the Amazon River mainstem (Brazil). Science of The Total Environment, 339(1-3): 219-232.

Viers, J., Roddaz, M., Filizola, N., Guyot, J-L., Sondag, F., Brunet, P., Zouiten, C., Boucayrand, C., Martin, F., Boaventura, G.R., 2008. Seasonal and provenance controls on $\mathrm{Nd}-\mathrm{Sr}$ isotopic compositions of Amazon rivers suspended sediments and implications for $\mathrm{Nd}$ and $\mathrm{Sr}$ fluxes exported to the Atlantic Ocean. Earth and Planetary Science Letters, 274(3-4): 511-523.

Vital, H., Stattegger, K., 2000. Major and trace elements of stream sediments from the lowermost Amazon River. Chemical Geology, 168(1-2): 151-168.

Waliser, D.E., Gautier, C., 1993. A satellite-derived climatology of the ITCZ. Journal of Climate, 6(11): 2162-2174.

Wittmann, H., Von Blanckenburg, F., Maurice, L., Guyot, J.-L., Kubik, P., 2011. Recycling of Amazon floodplain sediment quantified by cosmogenic 26Al and 10Be. Geology, 39(5): 467-470.

Zhang, Y., Chiessi, C.M., Mulitza, S., Zabel, M., Trindade, R.I.F., Hollanda, M.H.B.M., Dantas, E.L., Govin, A., Tiedemann, R., Wefer, G., 2015. Origin of increased terrigenous supply to the NE South American continental margin during Heinrich Stadial 1 and the Younger Dryas. Earth and Planetary Science Letters, 432: 493-500.

Zhou, J., Lau, K., 1998. Does a monsoon climate exist over South America? Journal of Climate, 11(5): 1020-1040.

\section{Tables and figures captions:}

Table 1: Date and location of suspended particulate matter (SPM) sampling of the Amazon, Orinoco and the Maroni Rivers and corresponding discharges, SPM concentration and relative mineralogical composition. ${ }^{1}$ Discharges are expressed as monthly average values, Daily discharge values are accessible on Hybam website.

Table 2: Major and trace elements concentrations; $\mathrm{Al} / \mathrm{Si}, \mathrm{Cr} / \mathrm{Th}$ and $\mathrm{Th} / \mathrm{Sc}$ ratios; and Chemical Index of Alteration (CIA) in SPM from the Amazon, Orinoco and Maroni Rivers. ${ }^{1}$ GA standard values reported for comparison are from (Abbey, 1980).

Table 3: REE concentrations and Nd-Sr isotopic of SPM from the Amazon, Orinoco and Maroni Rivers. ${ }^{1}$ GA standard values reported for comparison are from (Abbey, 1980).

Figure 1: Map representing the drainage basin of the Amazon (light blue), Orinoco (dark blue) and Maroni Rivers (brown) together with the Andes, the Guyana and Brazilian shields. The red dots indicate the location of the hydrological station where suspended particulate matter (SPM) were sampled (i.e. Ciudad Bolivar for the Orinoco, Langa Tabiki for the Maroni and Óbidos for the Amazon). The width of the arrows represent the sediments fluxes of the rivers.

Figure 2: 1986-2015 average rainfall distribution over northern South America during JJA (June-July-August) and DJF (December-January-February) periods (source : CAMSOPI data through clim explorer website https://climexp.knmi.nl). The 1986-2015 monthly runoff average for Amazon, Orinoco and Maroni Rivers basins is added for reference. 
Figure 3: Daily discharge (Hybam website) and suspended particulate matter (SPM) concentrations sampled once a month for the Amazon, Orinoco and Maroni Rivers during the periods covered in this study.

Figure 4: a) Semi quantitative mineralogical compositions of Amazon, Orinoco and Maroni SPM expressed relative frequency of integrated XRD peaks signals and annually averaged for each river. b) Quartz content versus SPM concentration plot (logarithmic fitting for Amazon and Orinoco are also represented.)

Figure 5: Major and selected trace element compositions of Amazon, Orinoco and Maroni SPM normalized to PAAS (Pourmand et al., 2012) and corrected with $\left[\mathrm{Al}_{2} \mathrm{O}_{3}\right]_{\text {PAAS }} /\left[\mathrm{Al}_{2} \mathrm{O}_{3}\right]_{\text {Sample ratios. }}$ From the left to the right abscissa of the diagram are plotted major elements $\left(\mathrm{SiO}_{2}, \mathrm{Al}_{2} \mathrm{O}_{3}, \mathrm{MnO}, \mathrm{MgO}, \mathrm{CaO}, \mathrm{Na}_{2} \mathrm{O}, \mathrm{K}_{2} \mathrm{O}, \mathrm{TiO}_{2}, \mathrm{P}_{2} \mathrm{O}_{5}\right)$, large ion lithophile elements (LILE) (Rb, Ba, Cs, Sr, Th and U), high field strength elements (HFSE) (Zr, Hf, Y and $\mathrm{Nb}$ ), and transition trace elements (TTE) $(\mathrm{Cr}, \mathrm{Ci}, \mathrm{V})$.

Figure 6: Rare earth element (REE) concentrations compositions of Amazon, Orinoco and Maroni SPM normalized against PAAS (Pourmand and al., 2012) and corrected wtih $\left[\mathrm{Al}_{2} \mathrm{O}_{3}\right]_{\text {PAAS }} /\left[\mathrm{Al}_{2} \mathrm{O}_{3}\right]_{\text {Sample. }}$ REE patterns of clays from Amazon and Orinoco Rivers published by Bayon et al. 2015 are reported for comparison as black curves.

Figure 7: Cross plot comparing the variation in $\mathrm{Al} / \mathrm{Si}, \mathrm{CIA}, \varepsilon \mathrm{Nd}$ and $\mathrm{Sr}$ isotopic composition of the analysed SPM as a function of their mineralogy (quartz, mica + illite and kaolinite);

Figure 8: ${ }^{87} \mathrm{Sr} /{ }^{86} \mathrm{Sr}-\varepsilon \mathrm{Nd}$ signatures of Amazon Orinoco and Maroni SPM (this study, green triangles, blue diamonds and red squares) compared with data obtained from various areas of the Andes, the Amazonian and Orinoco basins. Data sources: Quaternary Ecuadorian lavas from (Barragan et al., 1998); Mesozoic and Neogene volcanic rocks from Rogers and Hawkesworth (1989) and from Kay et al. (1994). Data for Cenozoic sedimentary rocks of the Central Depression, Altiplano, Oriental Cordillera and Subandean Zone from Pinto (2003). Madeira and Solimões SPM from Viers et al. (2008). Orinoco and tributaries SPM $\varepsilon N d$ values from Golstein et al. 1997 (black arrows). Lower Orinoco sediments and SPM from Parra et al. 1997 (black diamonds).

Figure 9: Plot comparing SPM geochemical data with discharge and SPM concentrations for the Amazon, Orinoco and Maroni Rivers. Viers et al. (2008) ${ }^{87} \mathrm{Sr} /{ }^{86} \mathrm{Sr}$ and $\varepsilon \mathrm{Nd}$ datas from Madeira and Solimões Rivers are reported for comparison.

Figure 10: a) Plot of $\mathrm{Cr} / \mathrm{Th}$ vs $\mathrm{Th} / \mathrm{Sc}$ in SPM from the Amazon, Orinoco and Maroni Rivers. b) Plot of $\mathrm{Cr} / \mathrm{Th}$ vs $\varepsilon \mathrm{Nd}$ for Maroni SPM (white-red squares are considered outliers and were not included in regression)

Figure 11: a) Precipitations over Western Amazonia $\left(6^{\circ} \mathrm{S}-1^{\circ} \mathrm{N}, 79^{\circ} \mathrm{W}-70^{\circ} \mathrm{W}\right)$ from $1998-2018$ (dark green) and in 2012 (light green) and over South-western Amazonia $\left(18^{\circ} \mathrm{S}-12^{\circ} \mathrm{N}, 70^{\circ} \mathrm{W}\right.$ $62^{\circ} \mathrm{W}$ ) from 1998-2018 (dark blue) and in 2012 (light blue) extracted from clim explorer time series (https://climexp.knmi.nl/). Mean position of the ITCZ over South America $\left(75^{\circ} \mathrm{W}\right.$ $45^{\circ} \mathrm{W}$ ) estimated by Waliser and Gautier (1993). b) Plot of Amazon SPM $\varepsilon N d$ at Óbidos and the mean position of the ITCZ over South America $\left(75^{\circ} \mathrm{W}-45^{\circ} \mathrm{W}\right)$ estimated by Waliser and Gautier (1993). Using a four months lag, the ITCZ position gets in phase with the isotopic signal observed in Óbidos. 
Table 1

\begin{tabular}{|c|c|c|c|c|c|c|c|}
\hline Sample & month & date & Discharge $^{1}$ & mg. $\mathbf{l}^{-1}$ & $\begin{array}{c}\text { Mica } \\
\text { Illite } \\
\text { Rel. Int } \\
\%\end{array}$ & Rel. Int \% & $\begin{array}{c}\text { Quartz } \\
\text { Rel. Int } \\
\frac{\%}{}\end{array}$ \\
\hline \multicolumn{8}{|c|}{ Amazon at Óbidos $\left(01.9225^{\circ} \mathrm{S} ; 55.6753^{\circ}\right)$} \\
\hline OB 02 & Feb & $10 / 02 / 12$ & 195900 & 110.2 & 0.25 & 0.22 & 0.53 \\
\hline OB 03 & Mar & $10 / 03 / 12$ & 231000 & 69.8 & 0.27 & 0.19 & 0.54 \\
\hline OB 04 & Apr & $10 / 04 / 12$ & 240200 & 9.3 & 0.38 & 0.32 & 0.29 \\
\hline OB 05 & May & $10 / 05 / 12$ & 247600 & 21.8 & 0.30 & 0.33 & 0.37 \\
\hline OB 06 & Jun & $10 / 06 / 12$ & 254500 & 10.9 & 0.37 & 0.33 & 0.30 \\
\hline OB 07 & Jul & $10 / 07 / 12$ & 258300 & 8.0 & 0.39 & 0.34 & 0.27 \\
\hline OB 08 & Aug & $10 / 08 / 12$ & 231200 & 29.3 & 0.28 & 0.26 & 0.47 \\
\hline OB 09 & Sep & $10 / 09 / 12$ & 157100 & 10.4 & 0.41 & 0.38 & 0.21 \\
\hline OB 10 & Oct & $10 / 10 / 12$ & 93460 & 12.4 & 0.35 & 0.39 & 0.26 \\
\hline OB 11 & Nov & $10 / 11 / 12$ & 80860 & 15.6 & 0.36 & 0.43 & 0.21 \\
\hline OB12 & Dec & $10 / 12 / 12$ & 90490 & 115.3 & 0.26 & 0.19 & 0.56 \\
\hline OB13 & Jan & 10/01/13 & 133600 & 159.7 & nd & & nd \\
\hline \multicolumn{8}{|c|}{ Orinoco at Ciudad bolivar $\left(08.1536^{\circ} \mathrm{N} ; 063.5361^{\circ} \mathrm{W}\right)$} \\
\hline ORI 01 & Jan & 10/01/08 & 14760 & 34.9 & 0.24 & 0.30 & 0.45 \\
\hline ORI 02 & Feb & $10 / 02 / 08$ & 7469 & 13.3 & 0.30 & 0.41 & 0.29 \\
\hline ORI 03 & Mar & $10 / 03 / 08$ & 6856 & 23.3 & 0.29 & 0.44 & 0.27 \\
\hline ORI 04 & Apr & $10 / 04 / 08$ & 5959 & 10.0 & 0.29 & 0.46 & 0.25 \\
\hline ORI 05 & May & $10 / 05 / 08$ & 15090 & 52.7 & 0.25 & 0.48 & 0.27 \\
\hline ORI 06 & Jun & $10 / 06 / 08$ & 33720 & 158.2 & nd & nd & nd \\
\hline ORI 07 & Jul & $10 / 07 / 08$ & 53970 & 112.4 & 0.17 & 0.23 & 0.60 \\
\hline ORI 08 & Aug & $10 / 08 / 08$ & 68530 & 13.8 & 0.30 & 0.42 & 0.28 \\
\hline ORI 09 & Sep & $10 / 09 / 08$ & 62900 & 27.3 & 0.27 & 0.33 & 0.40 \\
\hline ORI 10 & Oct & $10 / 10 / 08$ & 48600 & 24.7 & 0.26 & 0.36 & 0.39 \\
\hline ORI 11 & Nov & $10 / 11 / 08$ & 36890 & 55.1 & 0.22 & 0.28 & 0.50 \\
\hline ORI 12 & Dec & 11/12/08 & 32530 & 98.4 & nd & nd & nd \\
\hline \multicolumn{8}{|c|}{ Maroni at Langa Tabiki $\left(05.1401^{\circ} \mathrm{S} ; 054.3551^{\circ} \mathrm{W}\right)$} \\
\hline MAR 01 & Jan & 18/01/08 & 1784 & 30.2 & 0.08 & 0.90 & 0.02 \\
\hline MAR 02 & Feb & $13 / 02 / 08$ & 2763 & 36.0 & 0.10 & 0.85 & 0.05 \\
\hline MAR 03 & Mar & $13 / 03 / 08$ & 2840 & 30.9 & 0.09 & 0.87 & 0.04 \\
\hline MAR 04 & Apr & $15 / 04 / 08$ & 2929 & 18.9 & 0.14 & 0.80 & 0.07 \\
\hline MAR 05 & May & $10 / 05 / 08$ & 4486 & 22.0 & 0.07 & 0.90 & 0.03 \\
\hline MAR 06 & Jun & $10 / 06 / 08$ & nd & 15.1 & 0.08 & 0.90 & 0.02 \\
\hline MAR 07 & Jul & $11 / 07 / 08$ & 3939 & 16.9 & 0.09 & 0.89 & 0.02 \\
\hline MAR 08 & Aug & $14 / 08 / 08$ & 2421 & 14.4 & 0.08 & 0.87 & 0.05 \\
\hline MAR 09 & Sep & $17 / 09 / 08$ & 1333 & 20.7 & 0.10 & 0.89 & 0.01 \\
\hline MAR 10 & Oct & 09/10/08 & 854.3 & 15.1 & 0.08 & 0.88 & 0.04 \\
\hline MAR 11 & Nov & $13 / 11 / 08$ & 402.5 & 6.9 & 0.12 & 0.83 & 0.05 \\
\hline MAR 12 & Dec & $15 / 12 / 08$ & 598.4 & 18.0 & 0.17 & 0.77 & 0.06 \\
\hline
\end{tabular}


Table 2

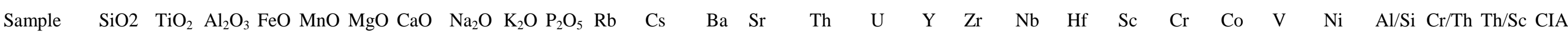

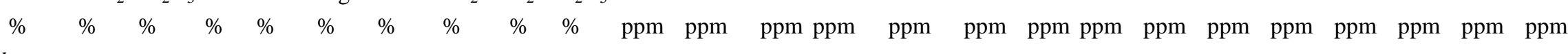

Amazon at Óbidos

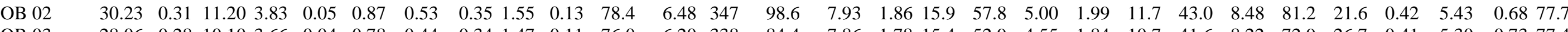
$\begin{array}{lllllllllllllllllllllllllllllll}\text { OB } 03 & 28.06 & 0.28 & 10.10 & 3.66 & 0.04 & 0.78 & 0.44 & 0.34 & 1.47 & 0.11 & 76.0 & 6.20 & 338 & 84.4 & 7.86 & 1.78 & 15.4 & 52.9 & 4.55 & 1.84 & 10.7 & 41.6 & 8.22 & 72.9 & 26.7 & 0.41 & 5.30 & 0.73 & 77.4\end{array}$

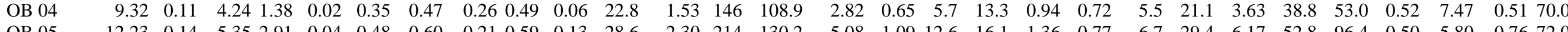

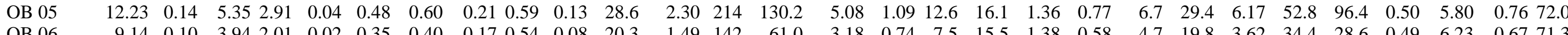

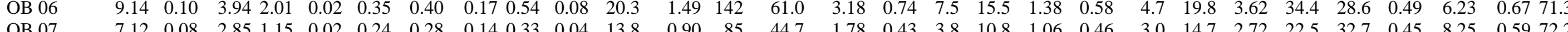
$\begin{array}{lrllllllllllllllllllllllllllllll}\text { OB } 07 & 7.12 & 0.08 & 2.85 & 1.15 & 0.02 & 0.24 & 0.28 & 0.14 & 0.33 & 0.04 & 13.8 & 0.90 & 85 & 44.7 & 1.78 & 0.43 & 3.8 & 10.8 & 1.06 & 0.46 & 3.0 & 14.7 & 2.72 & 22.5 & 32.7 & 0.45 & 8.25 & 0.59 & 72.2 \\ \text { OB 08 } & 17.48 & 0.18 & 632 & 2.86 & 0.03 & 0.51 & 0.57 & 0.25 & 0.82 & 0.10 & 36.3 & 2.58 & 218 & 81.3 & 4.77 & 1.11 & 11.4 & 33.3 & 2.52 & 1.25 & 7.0 & 25.4 & 5.93 & 49.3 & 53.4 & 0.41 & 5.34 & 0.68 & 73.0\end{array}$

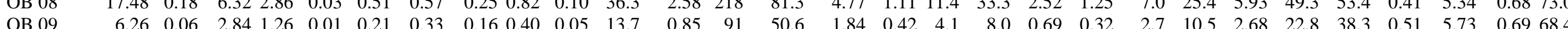

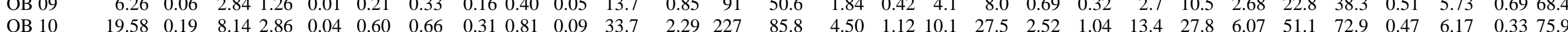

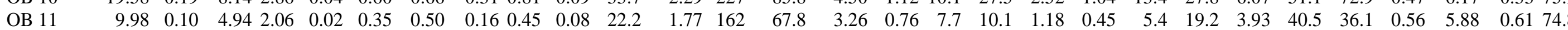

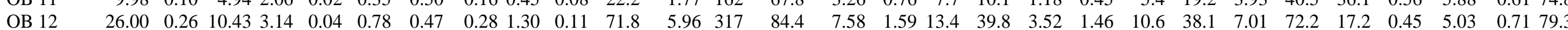
$\begin{array}{llllllllllllllllllllllllllllllll}\text { OB } 13 & 66.93 & 0.66 & 26.96 & 8.71 & 0.10 & 1.90 & 1.35 & 0.77 & 3.00 & 0.31 & 167.0 & 13.68 & 772 & 265.7 & 17.57 & 4.36 & 34.7 & 86.8 & 10.22 & 3.50 & 24.1 & 98.8 & 18.83 & 200.9 & 77.8 & 0.46 & 5.62 & 0.73 & 79.4\end{array}$

ORI 01

RI 01

ORI 03

ORI 04

ORI 05

ORI 06

ORI 07

ORI 08

ORI 10 bolivar

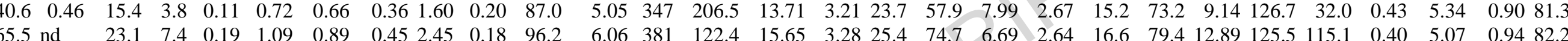

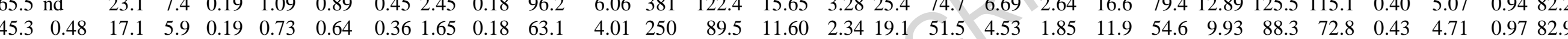

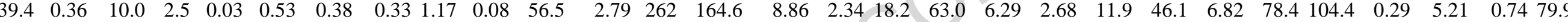

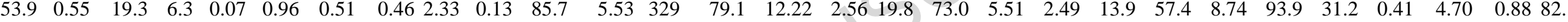

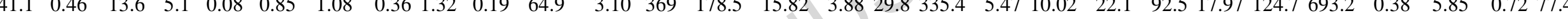

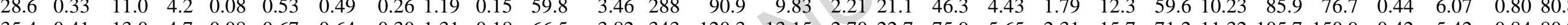
$\begin{array}{lllllllllllllllllllllllllllll}35.4 & 0.41 & 13.0 & 4.7 & 0.08 & 0.67 & 0.64 & 0.30 & 1.31 & 0.18 & 66.5 & 3.82 & 343 & 12.3 & 13.15 & 2.70 & 22.7 & 75.9 & 5.65 & 2.31 & 15.7 & 71.2 & 11.32 & 105.7 & 750.9 & 0.42 & 5.42 & 0.84 & 80.9\end{array}$ $\begin{array}{llllllllllllllllllllllllllllll}26.0 & 0.29 & 9.5 & 2.8 & 0.05 & 0.44 & 0.32 & 0.23 & 1.14 & 0.11 & 58.3 & 3.51 & 258 & 112.7 & 8.95 & 1.91 & 17.2 & 56.8 & 4.23 & 2.03 & 11.2 & 46.5 & 5.20 & 75.1 & 10.0 & 0.42 & 5.20 & 0.80 & 81.2 \\ 43.3 & 0.47 & 15.5 & 5.2 & 0.07 & 0.78 & 0.45 & 0.34 & 1.8 & 0.16 & 98.4 & 0.07 & 402 & 117.5 & 14.38 & 3.09 & 25.5 & 9.5 & 6.20 & 3.24 & 16.6 & 4.7 & 11.28 & 113.4 & 50.4 & 0.40 & 4.50 & 0.87 & 8.2\end{array}$ $\begin{array}{lllllllllllllllllllllllllllllllll}37.0 & 0.37 & 13.4 & 4.4 & 0.05 & 0.70 & 0.34 & 0.29 & 1.64 & 0.14 & 91.0 & 5.69 & 339 & 96.3 & 12.02 & 2.60 & 20.7 & 72.5 & 5.68 & 2.56 & 14.1 & 55.7 & 9.05 & 96.2 & 34.3 & 0.41 & 4.63 & 0.85 & 82.4 & & & \end{array}$ ORI 12

MAR 01 $\begin{array}{lllllllllllllllllllllllllllll}9.8 & 0.18 & 7.1 & 2.3 & 0.04 & 0.12 & 0.17 & 0.11 & 0.25 & 0.05 & 5.32 & 0.43 & 103 & 54.1 & 3.08 & 0.53 & 3.7 & 15.4 & 0.84 & 0.50 & 7.5 & 50.3 & 5.61 & 52.5 & 3.9 & 0.82 & 16.30 & 0.41 & 90.3\end{array}$ $\begin{array}{lllllllllllllllllllllllllllllll}\text { MAR } 02 & 18.7 & 0.31 & 12.4 & 4.8 & 0.05 & 0.22 & 0.24 & 0.12 & 0.40 & 0.09 & 14.45 & 1.01 & 243 & 66.6 & 5.72 & 1.19 & 8.5 & 27.3 & 2.36 & 1.18 & 13.5 & 86.9 & 12.65 & 99.2 & 37.5 & 0.75 & 15.18 & 0.42 & 92.0 \\ \text { MAR 03 } & 10.8 & 0.19 & 7.5 & 2.8 & 0.04 & 0.13 & 0.20 & 0.09 & 0.31 & 0.06 & 8.57 & 0.55 & 151 & 54.6 & 3.78 & 0.73 & 5.1 & 19.9 & 1.4 & 0.75 & 7.8 & 48.6 & 7.33 & 58.0 & 41.3 & 0.79 & 12.86 & 0.49 & 89.7\end{array}$

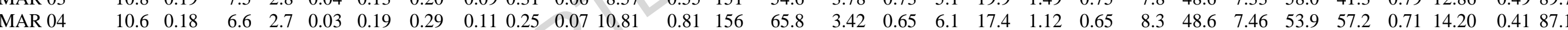
$\begin{array}{llllllllllllllllllllllllllllllll}\text { MAR } 05 & 9.0 & 0.16 & 6.6 & 2.4 & 0.04 & 0.17 & 0.28 & 0.10 & 0.25 & 0.07 & 4.11 & 0.31 & 102 & 64.8 & 4.35 & 0.71 & 4.4 & 12.6 & 1.35 & 0.51 & 6.5 & 37.7 & 7.80 & 46.4 & 76.8 & 0.82 & 8.67 & 0.67 & 87.5\end{array}$ $\begin{array}{llllllllllllllllllllllllllllllll}\text { MAR } 06 & 17.7 & 0.31 & 13.3 & 5.9 & 0.04 & 0.14 & 0.12 & 0.09 & 0.35 & 0.16 & 12.03 & 1.02 & 176 & 42.6 & 13.54 & 1.93 & 8.9 & 29.6 & 4.24 & 1.22 & 10.8 & 64.0 & 8.74 & 90.9 & 40.8 & 0.85 & 4.73 & 1.25 & 94.6\end{array}$ $\begin{array}{lllllllllllllllllllllllllllllll}\text { MAR } 07 & 23.0 & 0.40 & 16.9 & 8.2 & 0.08 & 0.26 & 0.39 & 0.45 & 0.47 & 0.23 & 17.57 & 1.42 & 325 & 88.2 & 12.89 & 1.98 & 12.1 & 43.7 & 3.88 & 1.69 & 16.6 & 103.9 & 14.25 & 136.8 & 41.1 & 0.83 & 8.06 & 0.78 & 89.6\end{array}$ $\begin{array}{llllllllllllllllllllllllllllll}\text { MAR } 08 & 25.3 & 0.44 & 17.2 & 9.1 & 0.11 & 0.35 & 0.52 & 0.19 & 0.46 & 0.21 & 18.08 & 1.38 & 376 & 122.4 & 13.36 & 2.16 & 14.2 & 46.1 & 2.98 & 1.80 & 21.2 & 129.4 & 21.82 & 162.8 & 116.6 & 0.77 & 9.69 & 0.63 & 90.8\end{array}$

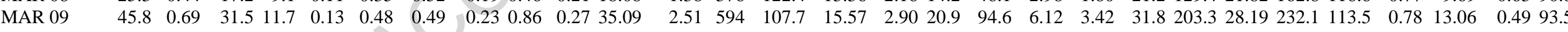

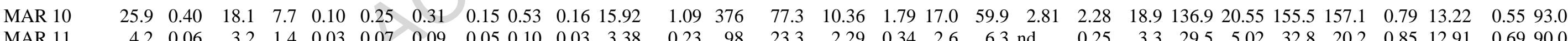

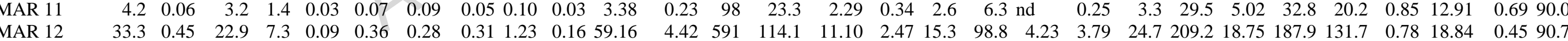

GA Standard

Average

$2 \mathrm{Sd}(\mathrm{n}=3$

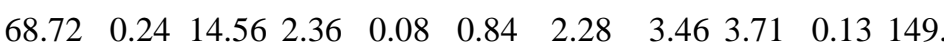

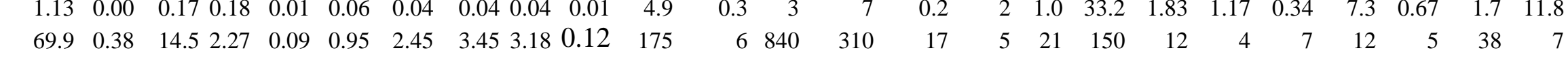

$\begin{array}{rrrrrrrrrrrrrr}5.5 & 792 & 290 & 14.8 & 5.1 & 17.3 & 97.1 & 3.58 & 3.19 & 10.18 & 11.7 & 4.02 & 38.8 & 9.8\end{array}$ 
Table 3

$\begin{array}{lcccccccccccccccccccccc}\text { Sample } & \mathrm{La} & \mathrm{Ce} & \mathrm{Pr} & \mathrm{Nd} & \mathrm{Sm} & \mathrm{Eu} & \mathrm{Gd} & \mathrm{Tb} & \mathrm{Dy} & \mathrm{Ho} & \mathrm{Er} & \mathrm{Tm} & \mathrm{Yb} & \mathrm{Lu} & \frac{\mathrm{Eu}_{\mathrm{n}}}{\mathrm{Nd}_{\mathrm{n}}} & \frac{\mathrm{Gd}_{n}}{\mathrm{Gd}_{\mathrm{n}}} & { }^{143} \mathrm{Nd} & { }^{2} \mathrm{SEM} & \varepsilon \mathrm{Nd}(0) & +/- & { }^{87} \mathrm{Sr} & { }^{86} \mathrm{Sr}\end{array}$ Amazon at Óbidos

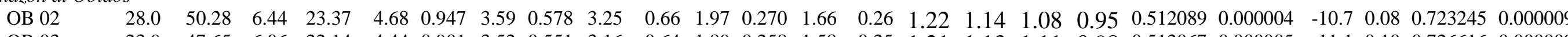
$\begin{array}{lllllllllllllllllllllllll}\text { OB } 03 & 23.9 & 47.65 & 6.06 & 22.14 & 4.44 & 0.901 & 3.52 & 0.551 & 3.16 & 0.64 & 1.89 & 0.258 & 1.58 & 0.25 & 1.21 & 1.13 & 1.11 & 0.98 & 0.512067 & 0.000005 & -11.1 & 0.10 & 0.726616 & 0.000009\end{array}$

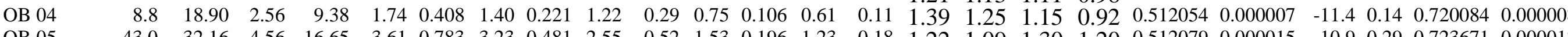
\begin{tabular}{llllllllllllllllllllllllll} 
OB 05 & 43.0 & 32.16 & 4.56 & 16.65 & 3.61 & 0.783 & 3.23 & 0.481 & 2.55 & 0.52 & 1.53 & 0.196 & 1.23 & 0.18 & 1.22 & 1.09 & 1.30 & 1.20 & 0.512079 & 0.000015 & -10.9 & 0.29 & 0.723671 & 0.000018 \\
\hline
\end{tabular}

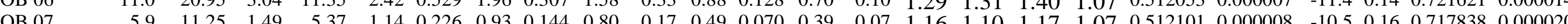

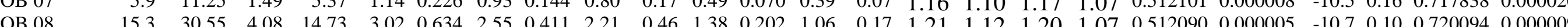
$\begin{array}{llllllllllllllllllllllllll}\mathrm{OB} & 09 & 6.8 & 11.99 & 1.58 & 5.82 & 1.24 & 0.280 & 1.04 & 0.165 & 0.86 & 0.18 & 0.51 & 0.076 & 0.39 & 0.07 & 1.31 & 1.12 & 1.20 & 1.07 & 0.512087 & 0.000009 & -10.7 & 0.18 & 0.718524 & 0.000012\end{array}$

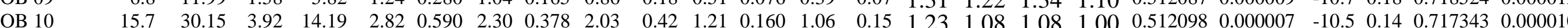
$\begin{array}{llllllllllllllllllllllllllll}\mathrm{OB} & 11 & 12.1 & 22.67 & 2.94 & 10.85 & 2.26 & 0.520 & 1.96 & 0.303 & 1.57 & 0.33 & 0.91 & 0.126 & 0.72 & 0.12 & 1.31 & 1.21 & 1.35 & 1.12 & 0.512134 & 0.000009 & -9.8 & 0.18 & 0.718239 & 0.000008\end{array}$ $\begin{array}{lllllllllllllllllllllllllll}\text { OB } 12 & 22.5 & 45.41 & 5.70 & 20.83 & 4.21 & 0.816 & 3.12 & 0.508 & 2.84 & 0.58 & 1.71 & 0.237 & 1.47 & 0.22 & 1.19 & 1.14 & 1.06 & 0.92 & 0.512135 & 0.000007 & -9.8 & 0.14 & 0.724153 & 0.000064\end{array}$ $\begin{array}{lllllllllllllllllllllllllll}\text { OB } 13 & 59.7 & 114.02 & 14.24 & 51.73 & 10.62 & 2.217 & 9.31 & 1.312 & 7.02 & 1.46 & 4.42 & 0.619 & 3.88 & 0.58 & 1.18 & 1.08 & 1.20 & 1.11 & 0.512137 & 0.000008 & -9.8 & 0.16 & 0.723868 & 0.000011\end{array}$ Orinoco at Ciudad bolivar

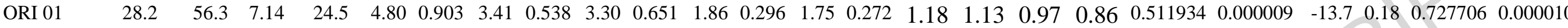

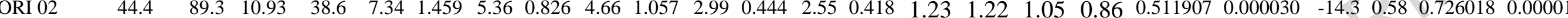
$\begin{array}{llllllllllllllllllllllllll}\mathrm{ORI} 03 & 45.8 & 94.6 & 11.50 & 40.1 & 7.87 & 1.487 & 5.60 & 0.842 & 5.26 & 1.035 & 3.06 & 0.421 & 2.72 & 0.441 & 1.18 & 1.19 & 1.02 & 0.86 & 0.511935 & 0.000006 & -13.7 & 0.12 & 0.725650 & 0.000008\end{array}$

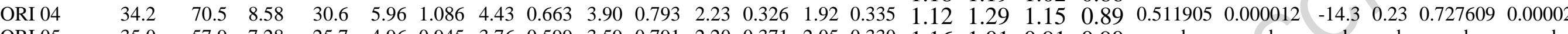

ORI 07

ORI 12 Maroni at Langa Tabili

MAR 01 MAR 02 MAR 03

MAR 04

MAR 05

MAR 06

MAR 08

MAR 09

MAR 11

MAR 12

Average

Average
$2 \mathrm{Sd}(\mathrm{n}=3$

Compiled

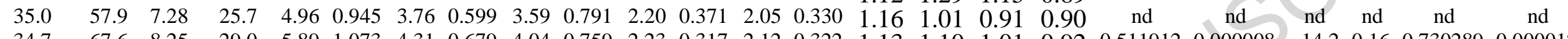

$\begin{array}{llllllllllllllllllllllll}34.7 & 67.6 & 8.25 & 29.0 & 5.89 & 1.073 & 4.31 & 0.679 & 4.04 & 0.759 & 2.23 & 0.317 & 2.12 & 0.322 & 1.13 & 1.10 & 1.01 & 0.92 & 0.511912 & 0.000008 & -14.2 & 0.16 & 0.730289 & 0.000012\end{array}$ $\begin{array}{llllllllllllllllllllllllll}5.3 & 100.6 & 12.55 & 43.4 & 8.67 & 1.514 & 6.30 & 0.944 & 5.94 & 1.236 & 3.40 & 0.583 & 3.51 & 0.574 & 1.08 & 1.00 & 0.90 & 0.90 & 0.51191 & 0.000010 & -14.2 & 0.19 & 0.730062 & 0.000012\end{array}$

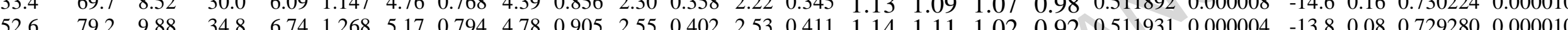

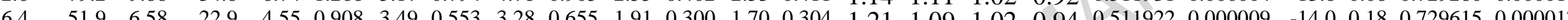
$\begin{array}{llllllllllllllllllllllllll}80.2 & 10.07 & 36.0 & 6.95 & 1.321 & 5.42 & 0.859 & 5.27 & 1.025 & 3.15 & 0.473 & 2.91 & 0.431 & 1.21 & 1.00 & 0.93 & 0.93 & 0.511918 & 0.000005 & -14.0 & 0.10 & 0.730605 & 0.000012\end{array}$

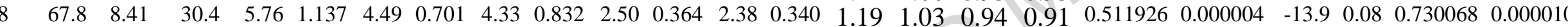

$\begin{array}{lllllllllllllllllllllllllllll}74.5 & 17.7 & 2.02 & 7.0 & 1.29 & 0.334 & 1.04 & 0.139 & 0.84 & 0.151 & 0.44 & 0.066 & 0.41 & 0.070 & 1.53 & 1.40 & 1.28 & 0.91 & 0.511387 & 0.000006 & -24.4 & 0.12 & 0.732866 & 0.000011\end{array}$

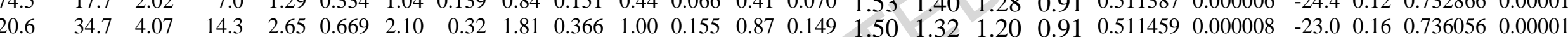
\begin{tabular}{llllllllllllllllllllllll}
13.2 & 22.9 & 2.65 & 9.2 & 1.71 & 0.452 & 1.23 & 0.189 & 1.15 & 0.221 & 0.62 & 0.089 & 0.59 & 0.092 & 1.64 & 1.25 & 1.04 & 0.83 & 0.511411 & 0.000010 & -23.9 & 0.19 & 0.736110 & 0.000015 \\
\hline
\end{tabular}

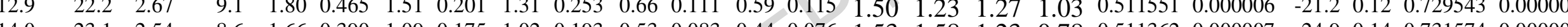
$\begin{array}{llllllllllllllllllllllll}14.0 & 23.1 & 2.54 & 8.6 & 1.66 & 0.390 & 1.09 & 0.175 & 1.02 & 0.193 & 0.53 & 0.083 & 0.44 & 0.076 & 1.53 & 1.58 & 1.23 & 0.78 & 0.511362 & 0.000007 & -24.9 & 0.14 & 0.731574 & 0.000009\end{array}$ $\begin{array}{llllllllllllllllllllllll}4.4 & 5.9 & 5.77 & 19.3 & 3.52 & 0.779 & 2.44 & 0.369 & 1.96 & 0.393 & 1.01 & 0.152 & 0.90 & 0.136 & 1.40 & 1.73 & 1.35 & 0.78 & 0.511346 & 0.000007 & -25.2 & 0.14 & 0.733496 & 0.0000098\end{array}$

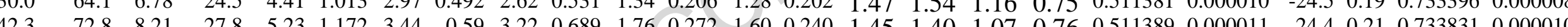

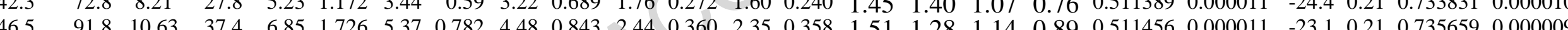

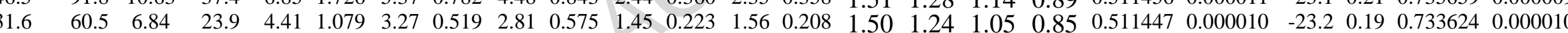
$\begin{array}{llllllllllllllllllllll} & \end{array}$

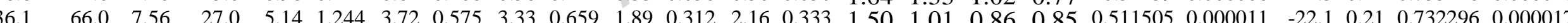

$\begin{array}{llllllllllllll}36.19 & 66.04 & 7.59 & 25.23 & 4.74 & 0.98 & 3.43 & 0.56 & 3.33 & 0.66 & 1.86 & 0.29 & 1.92 & 0.30\end{array}$

$\begin{array}{llllllllllllllll}10.19 & 12.15 & 1.38 & 3.46 & 0.54 & 0.05 & 0.12 & 0.04 & 0.27 & 0.04 & 0.15 & 0.03 & 0.28 & 0.03\end{array}$ 


\section{Highlights}

- Distinct SPM geochemical signatures exported by tropical South American rivers.

- Control of source rock lithology and hydrological cycles on these SPM signatures.

- Potential applications for provenance study and past hydroclimate changes. 


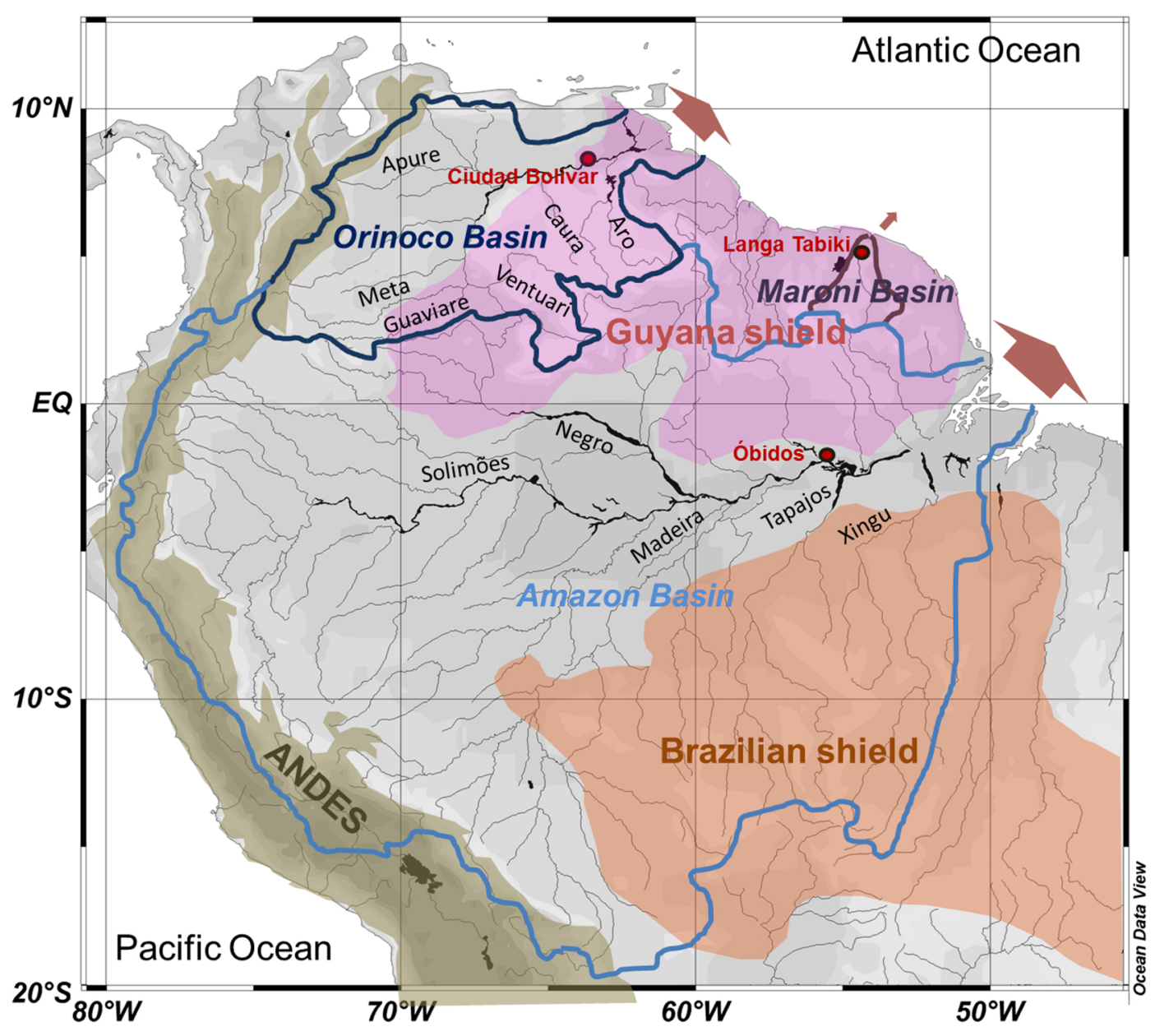

Figure 1 


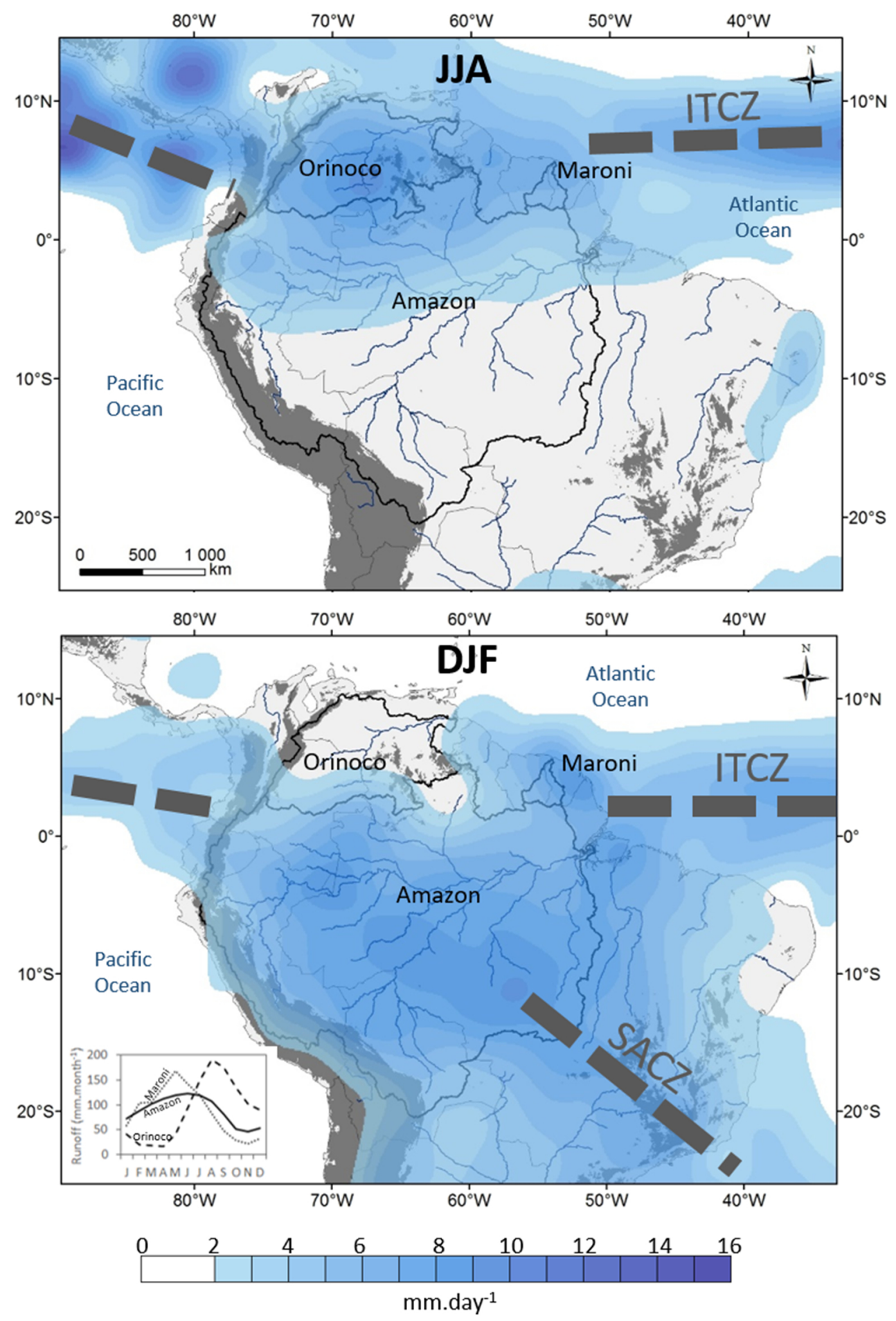




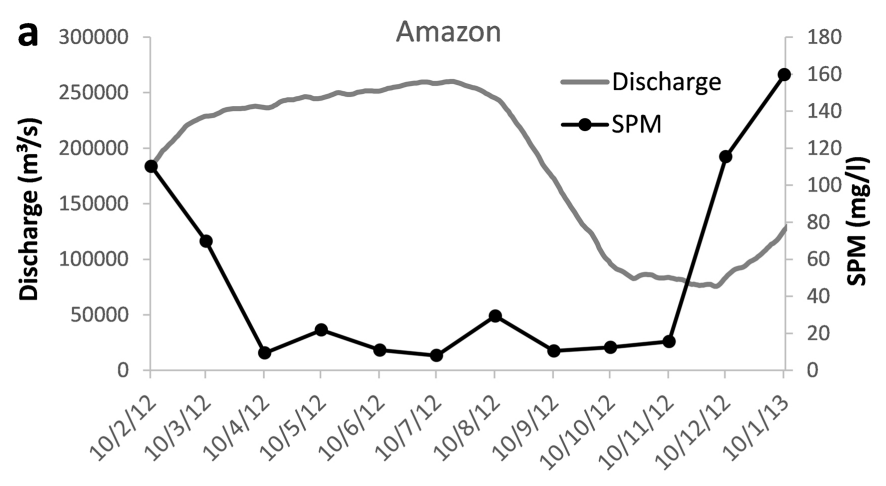

b

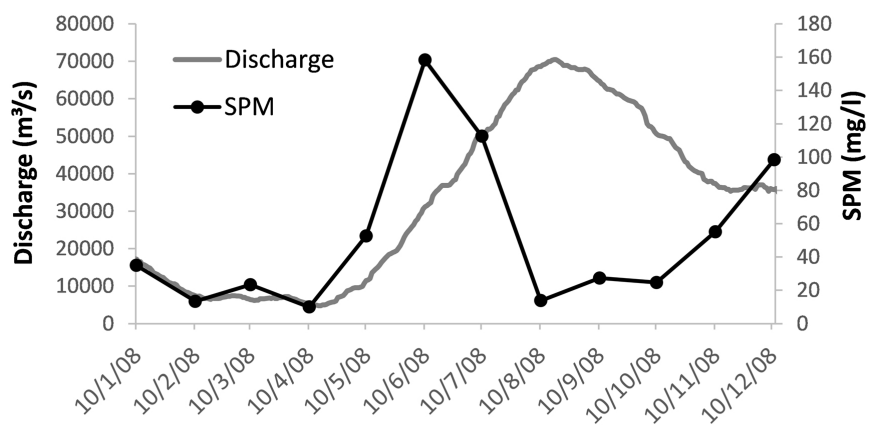

c

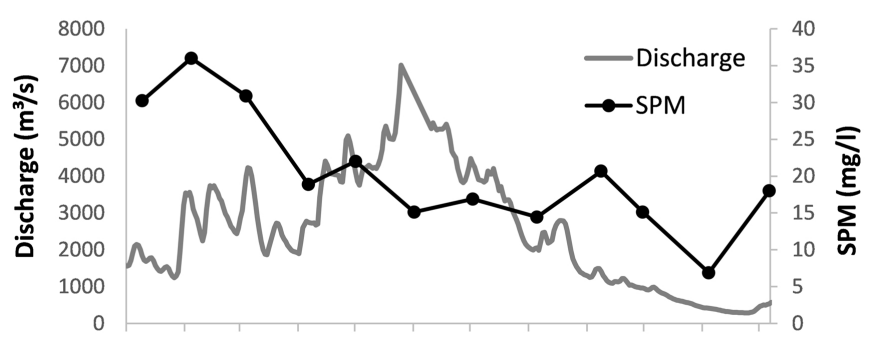

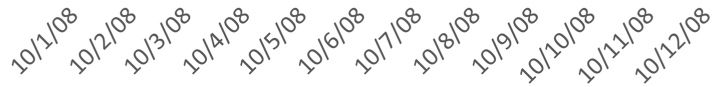


a
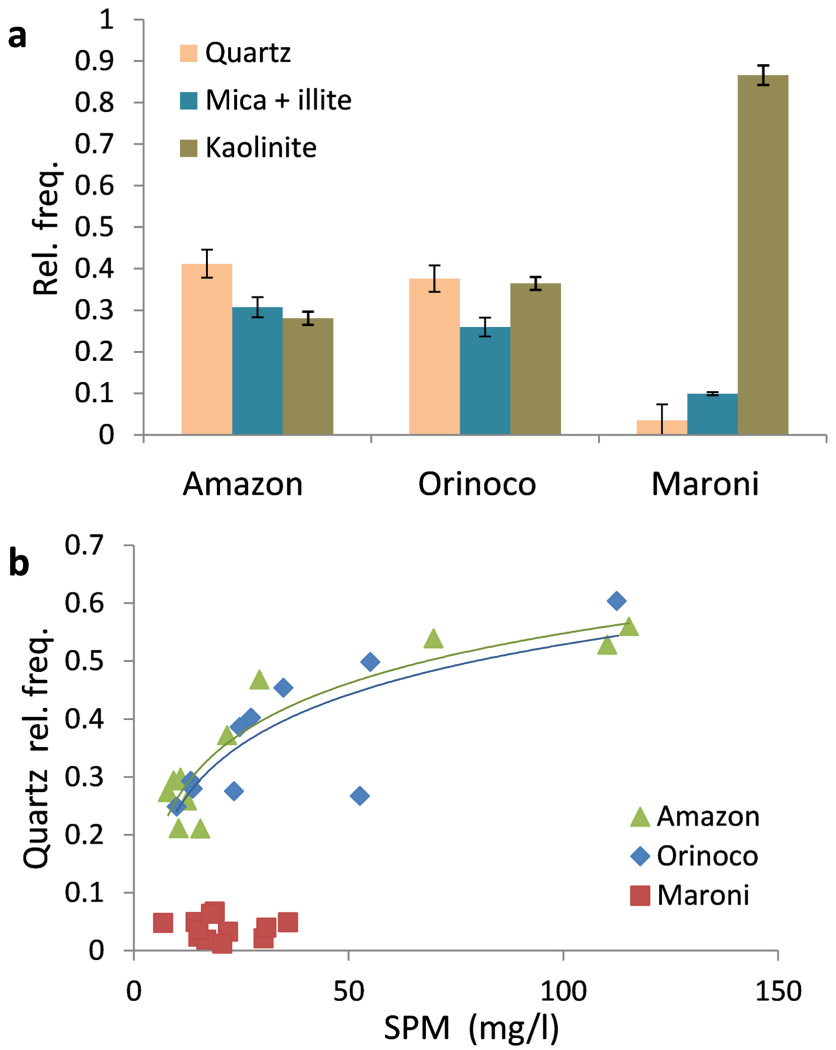

Figure 4 

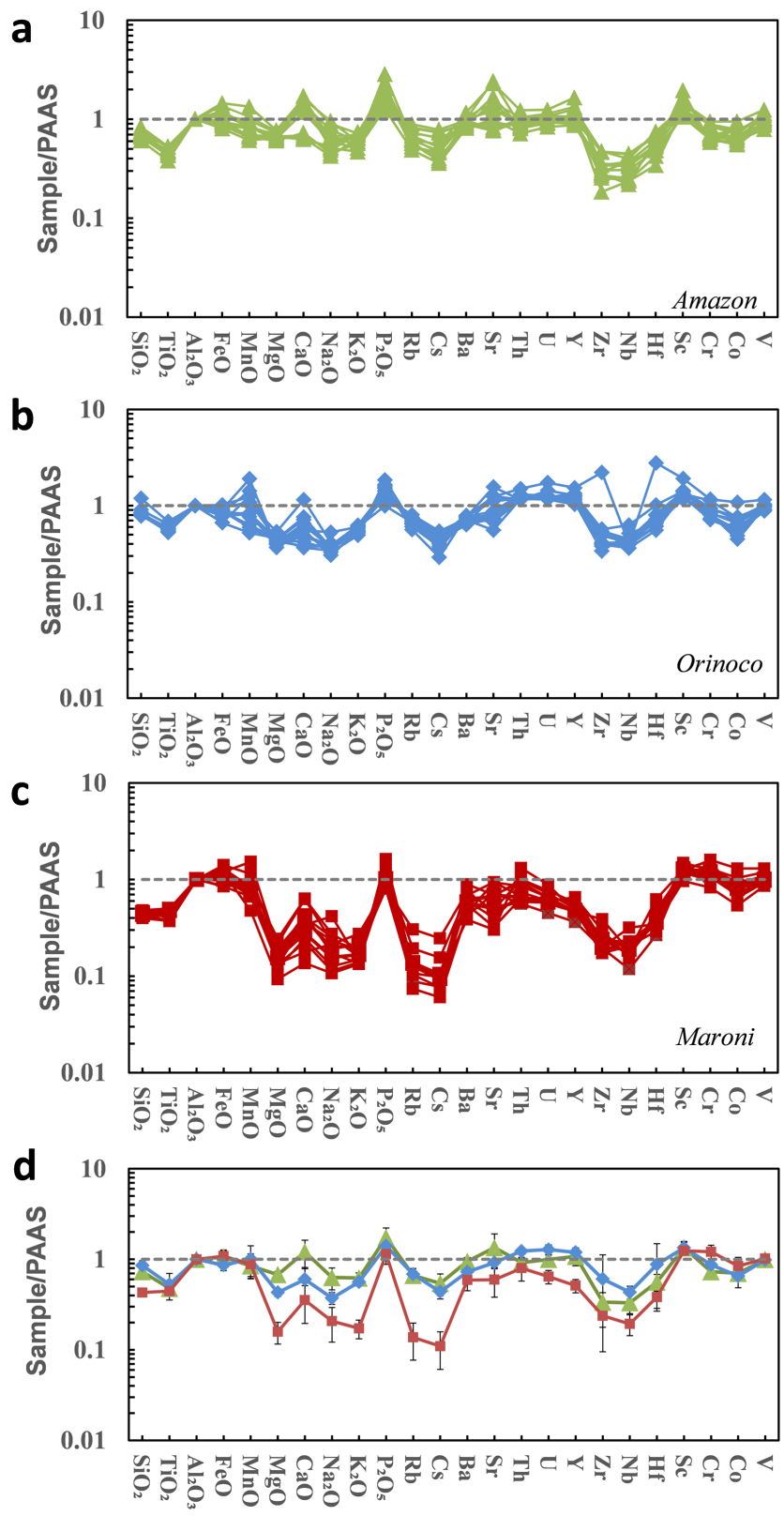

Figure 5 


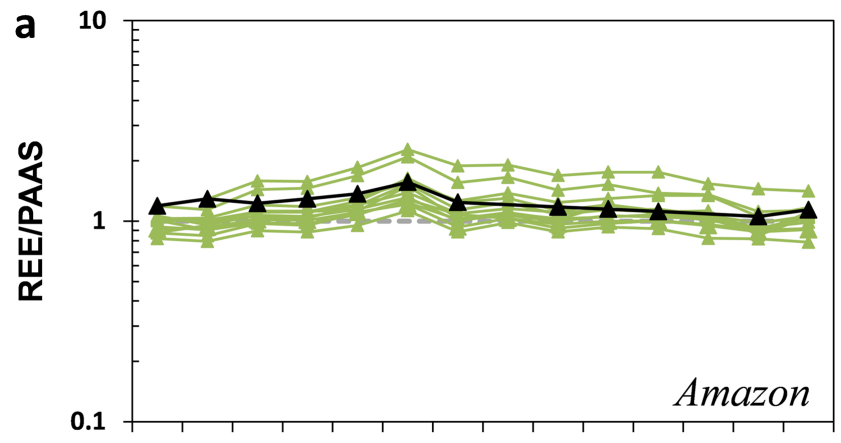

La Ce Pr Nd Sm Eu Gd Tb Dy Ho Er Tm Yb Lu

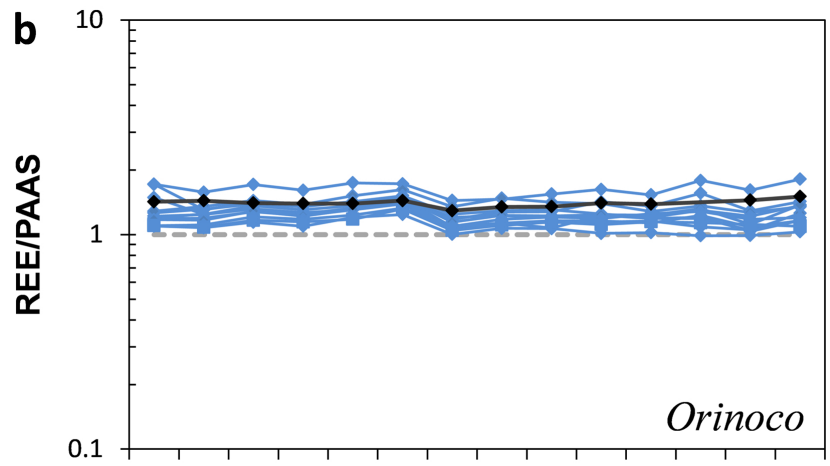

La Ce Pr Nd Sm Eu Gd Tb Dy Ho Er Tm Yb Lu

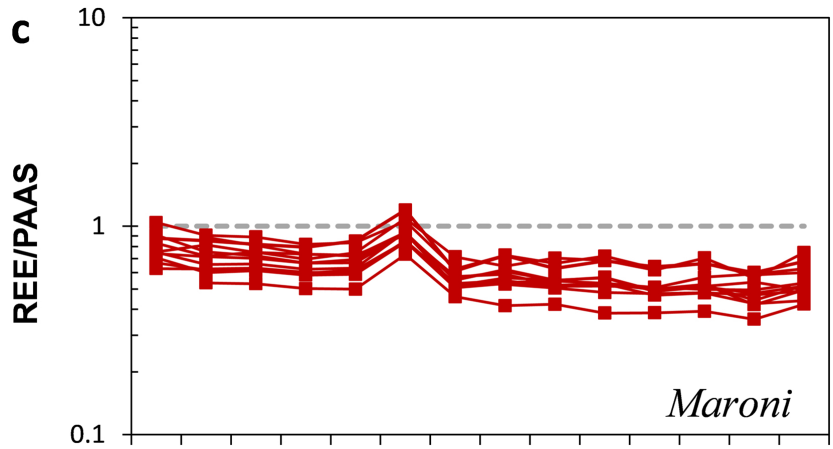

La Ce Pr Nd Sm Eu Gd Tb Dy Ho Er Tm Yb Lu 

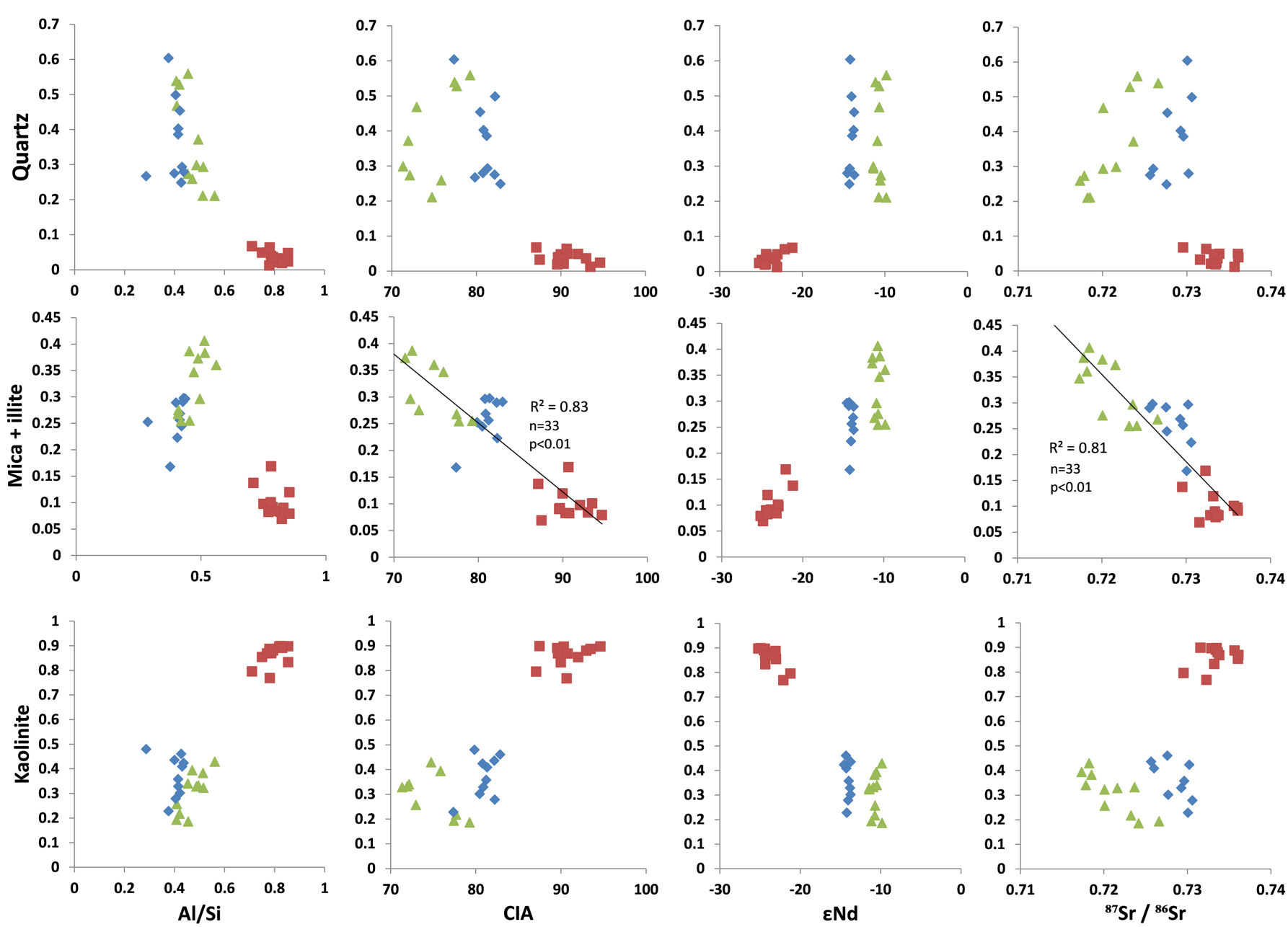

$\triangle$ Amazon Orinoco $\square$ Maroni 


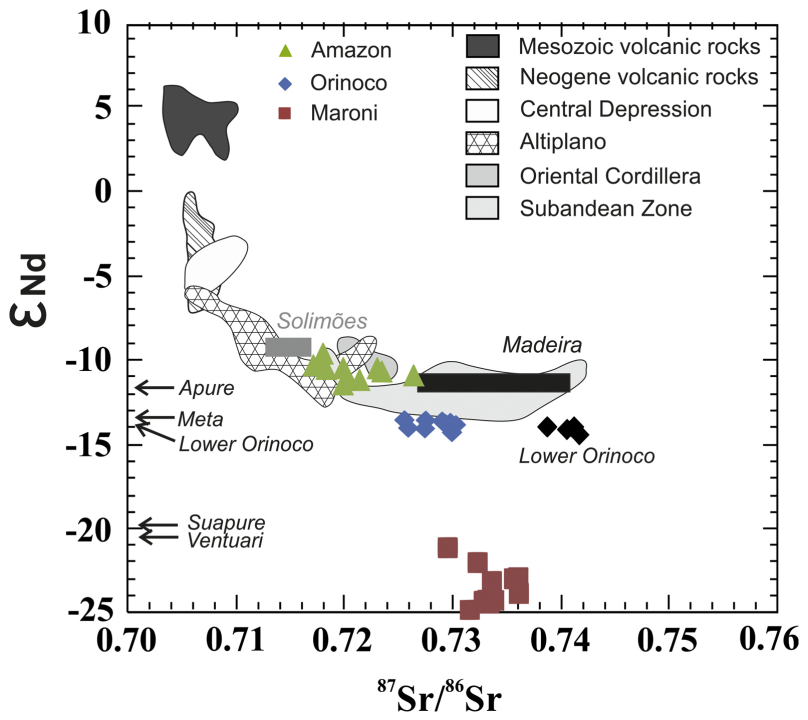

Figure 8 

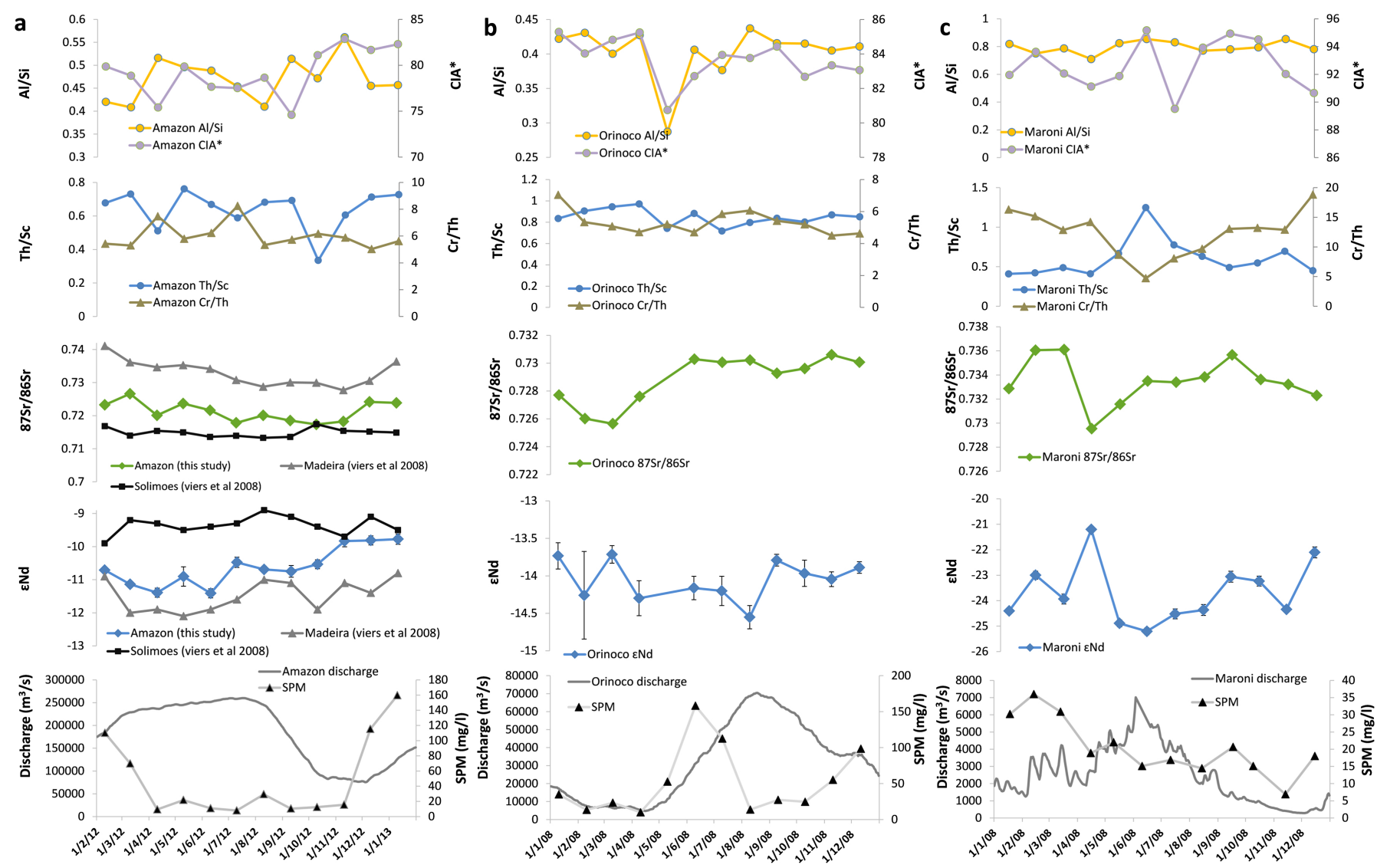

Figure 9 

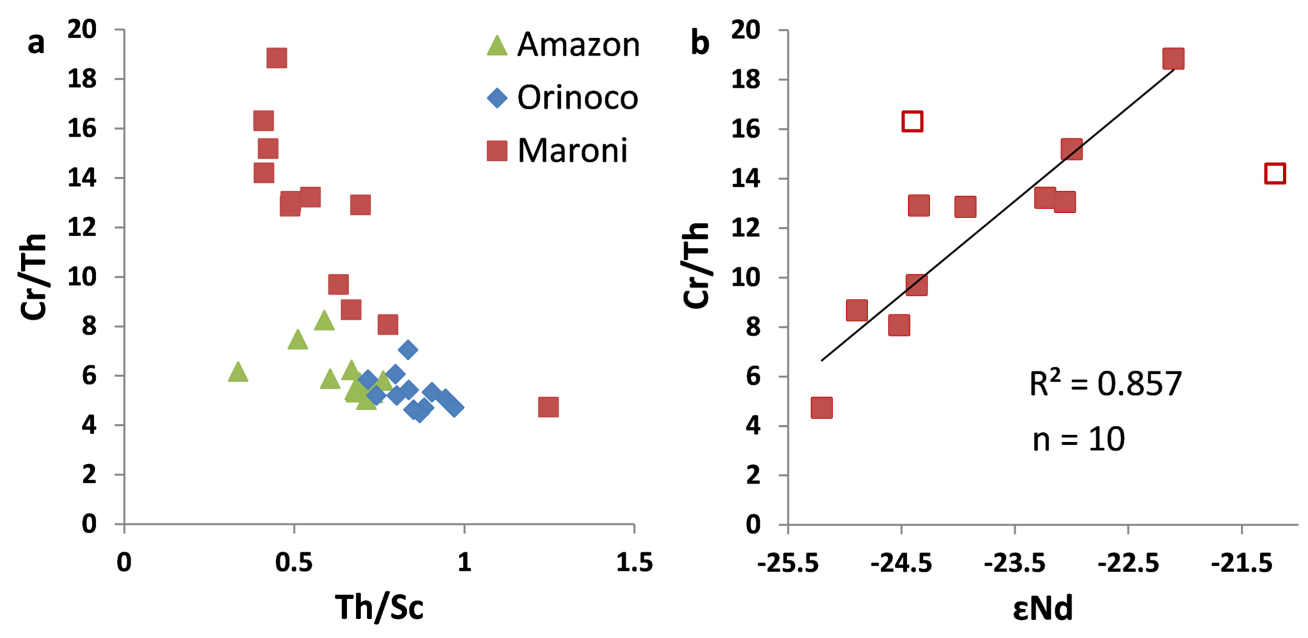

Figure 10 

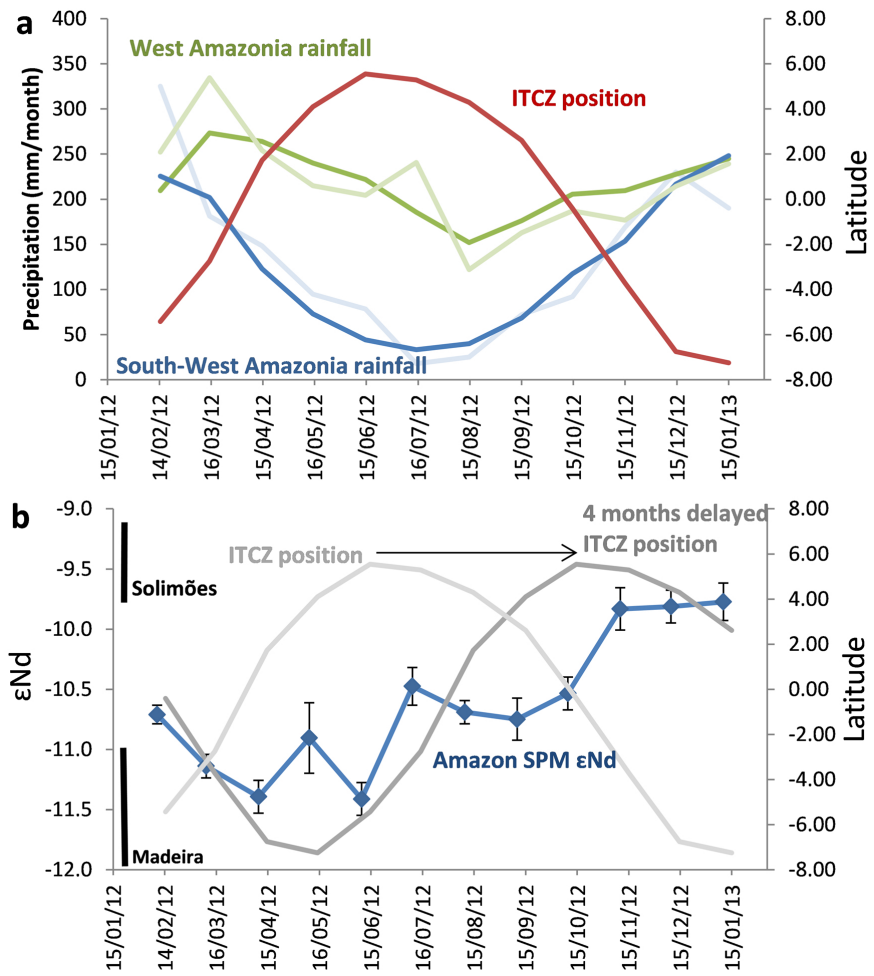

Figure 11 